\title{
Enterprise Resource Planning Readiness Assessment for Determining the Maturity Level of ERP Implementation in the Industry in Indonesia
}

\author{
Santo Fernandi Wijaya*,1, Harjanto Prabowo ${ }^{2}$, Ford Lumban Gaol ${ }^{3}$, Meyliana ${ }^{1}$ \\ ${ }^{1}$ Information Systems Department, School of Information System, Bina Nusantara University, Jakarta, 11480, Indonesia \\ ${ }^{2}$ Management Department, BINUS Business School Undergraduate Program, Bina Nusantara University, Jakarta, 11480, Indonesia \\ ${ }^{3}$ Computer Science Department, BINUS Graduate Program, Bina Nusantara University, Jakarta, 11480, Indonesia
}

A R T I C L E I N F O

Article history:

Received: 16 November, 2020

Accepted: 19 January, 2021

Online: 28 January, 2021

Keywords:

ERP readiness

Assessment

Maturity level

Textile industry

\begin{abstract}
A B S T R A C T
The textile industry is one of the prioritized industries, because it contributes to the country's foreign exchange, absorbs a large number of workers, and fulfills the need for national clothing. To increase work efficiency and productivity, the textile industry must use ERP. However, ERP implementation still has a relatively high failure rate. ERP readiness assessment is one of the main issues to achieve success in implementing ERP. Previous research is still limited to research about readiness for achieving success in ERP implementation. The research results have indicated that the maturity of the organization is a very significant dimension with a weight of $43.51 \%$. By knowing the maturity level of the organization for ERP implementation can identify factors that become weaknesses for organizations to take corrective steps, so as to reduce the failure rate of ERP implementation in the industry. This research methodology uses a quantitative approach using $R$ software to determine the principal component analysis and uses the Order Preference Technique with the Ideal Solution to weighted the identified factors. This research aims to determine organization readiness by developing the maturity level of ERP implementation in the industry in Indonesia which conducted a case study experiment in the textile industry in Indonesia. The result of this research is the development of an ERP readiness assessment to assess the maturity level of the organizations in ERP implementation.
\end{abstract}

\section{Introduction}

The textile industry is one of the industries that is prioritized for development because it has a strategic role in the national economy, namely as a contributor to foreign exchange, absorbing large numbers of workers, and to meet national clothing needs. To increase work efficiency and productivity, the textile industry must use ERP. ERP can improve the performance of an organization, but until now the ERP implementation for the industry still has complexity with a high failure rate, so this causes implementation costs to be expensive. Referring to previous research, the ERP readiness assessment can assess the readiness of an organization in implementing ERP. ERP readiness assessment can be reviewed from the perspective of top management, project management, people, change management, technical requirements [1]. By identifying the weaknesses factors

${ }^{*}$ Corresponding Author: Santo Fernandi Wijaya, santofw@binus.ac.id www.astesj.com

https://dx.doi.org/10.25046/aj060159 of the organization, management can develop ERP readiness assessment and make an evaluation to increase the organizational maturity level according to best practice [2-5]. The contribution of this research is the development of an ERP readiness measurement tool to increase the effectiveness of ERP implementation strategies for the industry, so that management can know the level of company readiness before making decisions for ERP implementation. Based on previous reseach, ERP implementations have a failure rate of $60 \%$ to $90 \%$. The problem solution is to identify critical success factors in ERP implementation with a focus on organization, technology adaptation, and business processes $[6,7]$. Also, by assessing the readiness of the organization, it can be evaluated the weaknesses and strengths of the organization to adapt to change, so that the company can achieve organizational agility and ERP implementation success [8-10]. Previous research shows that there is still little research that discusses the maturity assessment 
of an organization before top management decides to implement ERP. The development of ERP readiness assessment is one of the main issues related to achieving success in implementing ERP. This research can help the top management of an organization or consultant party to assess the maturity level before deciding to implement ERP with a discussion of four perspectives such as processes, people, organizational, and technology which based on the development of the Leavitt Diamond Model [11]. The four components of Leavitt Diamond Model are people, tasks or processes, technology, and structure or organization prominent success factors for improving industry performance. This matter is considered for organizations to assess the readiness level of an organization in implementing ERP, so that top management of the organization can find out the factors that are the weaknesses and strengths of the organization, to be able to make improvements, so that the relatively expensive investment value can achieve successful ERP implementation for an industry. This research explain identify the factors of ERP readiness assessment and the characteristics of the maturity level of the organization in ERP implementation. This is the novelty of this research which is the development of previous research to help the top management of the industry to find out the readiness of a company to adapt to a change in order to achieve the best practices and agile organizations.

\section{Experimental procedure}

The experimental procedure of this research uses a study case in the textile industry in Indonesia by using a quantitative approach technique with $\mathrm{R}$ software to determine the Principal Component Analysis (PCA) [12]. The objective of PCA is to reduce the data dimension by eliminating the correlation of variables by transforming the original variable into a new uncorrelated variable so that the data can be interpreted. PCA is a non-parametric method that uses linear algebra to extract relevant information or patterns from a dataset with multivariate attributes. This research also use of Technique for Order Preference Technique with the Ideal Solution (TOPSIS) method to identify the weight factors. The TOPSIS method approach can be used as an ERP assessment tool to determine the weighting and ranking of factors for the main weight, the weight of sub-factors, and the final weight. TOPSIS is a decision-making method for ranking and prioritizing Multi Criteria Decision Making (MCDM). The stages of weighting the TOPSIS method are as follows [13]:

1. Building a normalized weighted matrix using the following formula:

$$
Y_{i j}=\frac{X_{i j}}{\sqrt{\sum_{i=1}^{m} X^{2}{ }_{i j}}}
$$

2. Building a weighted normalized matrix by multiplying the normalized matrix with the weighting value of entropy weighting, with the normalization formula for the weighting matrix $\mathrm{v}$ as follows:

$$
\mathrm{V}=\left[\begin{array}{c}
V_{11} V_{12} \ldots . V_{1 n} \\
V_{21} V_{22} \ldots . V_{2 n} \\
V_{m 1} V_{m 2} \ldots . V_{m n}
\end{array}\right]=\left[\begin{array}{c}
W_{1 r 11} W_{2 r 12} \ldots W_{n r 1 n} \\
W_{1 r 21} W_{2 r 22} \ldots W_{n r 1 n} \\
W_{1 r m 1} W_{2 r m 2} \ldots W_{n r m n}
\end{array}\right]
$$

www.astesj.com
3. Determine the matrix for positive and negative ideal solutions. The positive ideal solution is denoted by $\mathrm{A}+$, while the negative ideal solution is denoted by A-. With the following formula:

$$
\begin{gathered}
\left.A^{*}=\left\{\left[\max _{i} V_{i j} \mid j \in J\right],\left[\min _{i} V_{i j} \mid j \in J^{1}\right]\right\} 1=1,2, \ldots . m\right\} \\
=\left\{V_{1}^{*} V_{2}^{*}, \ldots \ldots V_{j}^{*} \ldots \ldots V_{n}^{*}\right\} \\
\left.A^{-}=\left\{\left[\min _{i} V_{i j} \mid j \in J\right],\left[\max _{i} V_{i j} \mid j \in J^{1}\right]\right\} i=1,2, \ldots m\right\} \\
=\left\{V_{1}^{-} V_{2}^{-} \ldots \ldots V_{j}^{*} \ldots . V_{n}^{*}\right\}
\end{gathered}
$$

4. Calculate the distance between the value of each alternative solution with a positive ideal solution matrix and a negative ideal solution matrix. By using the following formula:

$$
\begin{aligned}
& S_{i}^{*}=\sqrt{\sum_{j=1}^{n}\left(V_{i j}-V_{i}^{*}\right)^{2},} \quad i=1,2, \ldots m \\
& S_{i}^{-}=\sqrt{\sum_{j=1}^{n}\left(V_{i j}-V_{i}^{-}\right)^{2},} \quad i=1,2, \ldots m
\end{aligned}
$$

5. Calculating the preference value to an alternative ideal solution, with the following formula:

$$
C_{i}^{*}=\frac{S_{i}^{-}}{S_{i}^{*}+S_{i}^{-}}
$$

6. Ranking the value of $\mathrm{Ci}+$. The best solution is to have the shortest distance to the ideal solution and the farthest distance to the ideal negative solution.

In processing the data of this study, the authors collected data from respondents using a questionnaire method. Then based on the results of the questionnaire, the authors validated the data using PCA. The results of data processing from PCA are to develop indicators as a basic concept in developing the ERP readiness assessment model. Based on the literature survey, the authors classify be indicators associated with these four dimensions. Based on the literature survey, the authors mapped the main variable (processes, people, organizational, and technology) with sub-variables and indicators related to the readiness of ERP implementation [14-18]. From the results of the literature survey, it was found that 24 sub-variables and 61 indicators affect organizational readiness in ERP implementation. Then the authors define indicators and make questionnaire statements, then the authors distribute data to respondents using a questionnaire method. A list of sub-variables, defining indicators and questionnaire statements can be seen in Table 1 . 
Table 1: Sub-variables, Indicators, Definition and Questionnaire Statement

\begin{tabular}{|c|c|c|c|c|c|c|}
\hline No & $\begin{array}{c}\text { Sub- } \\
\text { variables }\end{array}$ & No & Indicators & Code & Definition & Questionnaire statement \\
\hline \multirow{3}{*}{1} & \multirow{3}{*}{$\begin{array}{l}\text { Business } \\
\text { processes }\end{array}$} & 1 & $\begin{array}{l}\text { Committed to } \\
\text { change }\end{array}$ & PR01 & $\begin{array}{l}\text { Business process change need the organization commitment to } \\
\text { change to be standardized, understood and documented. }\end{array}$ & $\begin{array}{l}\text { The role of management's commitment to standardized, } \\
\text { understood, and documented changes to business } \\
\text { processes }\end{array}$ \\
\hline & & 2 & $\begin{array}{l}\text { Business } \\
\text { processes } \\
\text { change }\end{array}$ & PR02 & $\begin{array}{l}\text { Implementation success requires a change of business } \\
\text { processes. }\end{array}$ & $\begin{array}{l}\text { Changes in business processes to achieve successful ERP } \\
\text { implementation. }\end{array}$ \\
\hline & & 3 & $\begin{array}{l}\text { Business } \\
\text { processes } \\
\text { redesign }\end{array}$ & PR03 & $\begin{array}{l}\text { Redesigning the business processes of an organization to best } \\
\text { practice processes. }\end{array}$ & $\begin{array}{l}\text { It is necessary to redesign business processes based on best } \\
\text { practice business processes. }\end{array}$ \\
\hline \multirow[b]{2}{*}{2} & \multirow{2}{*}{$\begin{array}{c}\text { Process } \\
\text { standarized } \\
\text { based on } \\
\text { industry best } \\
\text { practice }\end{array}$} & 4 & $\begin{array}{l}\text { Integrated } \\
\text { business } \\
\text { process }\end{array}$ & PR04 & $\begin{array}{l}\text { Integrate business process and operations for improving } \\
\text { organization business. }\end{array}$ & $\begin{array}{l}\text { The integration of business processes and operations is } \\
\text { necessary to improve the organization's business. }\end{array}$ \\
\hline & & 5 & $\begin{array}{l}\text { Work } \\
\text { processes } \\
\text { standarized } \\
\text { and } \\
\text { documentation }\end{array}$ & PR05 & Standarization of work processes and documentation. & $\begin{array}{l}\text { Standardization of work processes and complete } \\
\text { documentation are essential in ERP implementation. }\end{array}$ \\
\hline \multirow{2}{*}{3} & \multirow{2}{*}{$\begin{array}{c}\text { Change } \\
\text { Management }\end{array}$} & 6 & $\begin{array}{l}\text { Cultural } \\
\text { change } \\
\text { management }\end{array}$ & PR06 & $\begin{array}{l}\text { Cultural change management is a concern to successfully } \\
\text { implement. }\end{array}$ & $\begin{array}{l}\text { Cultural change management must be done to ensure the } \\
\text { change process runs well. }\end{array}$ \\
\hline & & 7 & $\begin{array}{l}\text { Open minded } \\
\text { for changes }\end{array}$ & PR07 & Open minded for changes. & $\begin{array}{l}\text { An open mind from all parties involved in accepting the } \\
\text { change process. }\end{array}$ \\
\hline \multirow{3}{*}{4} & \multirow{3}{*}{$\begin{array}{l}\text { Skill and } \\
\text { competency }\end{array}$} & 8 & $\begin{array}{l}\text { Management's } \\
\text { skill and } \\
\text { competency }\end{array}$ & PE08 & $\begin{array}{l}\text { Management's skills determines the strategy of utilizing ERP } \\
\text { usage for business development. }\end{array}$ & $\begin{array}{l}\text { Management expertise in determining strategies for } \\
\text { utilizing ERP for business development. }\end{array}$ \\
\hline & & 9 & $\begin{array}{l}\text { User's skill } \\
\text { and } \\
\text { competency }\end{array}$ & PE09 & Skilled user to understand of process business of system used. & $\begin{array}{l}\text { User expertise in understanding the business processes of } \\
\text { the system used. }\end{array}$ \\
\hline & & 10 & $\begin{array}{l}\text { IT staff's skill } \\
\text { and } \\
\text { competency }\end{array}$ & PE10 & $\begin{array}{l}\text { Specialized skills and competency of the IT team will increase } \\
\text { the ERP implementation success. }\end{array}$ & $\begin{array}{l}\text { The expertise and special abilities of the IT team in } \\
\text { improving the success of ERP implementation. }\end{array}$ \\
\hline \multirow{2}{*}{5} & \multirow{2}{*}{$\begin{array}{l}\text { Project } \\
\text { Manager }\end{array}$} & 11 & $\begin{array}{l}\text { Adequate ERP } \\
\text { project } \\
\text { experience }\end{array}$ & PE11 & Project manager has adequate ERP project experience. & $\begin{array}{l}\text { The project manager has sufficient ERP project } \\
\text { experience. }\end{array}$ \\
\hline & & 12 & $\begin{array}{l}\text { High level } \\
\text { overview }\end{array}$ & PE12 & $\begin{array}{l}\text { Have a thorough understanding of the knowledge, experience, } \\
\text { ability, and coordinate all the processes of the ERP Project. }\end{array}$ & $\begin{array}{l}\text { Project Managers have a thorough understanding of the } \\
\text { knowledge, experience, capabilities, and coordinate all } \\
\text { processes in ERP implementation. }\end{array}$ \\
\hline \multirow{4}{*}{6} & \multirow{4}{*}{ Training } & 13 & $\begin{array}{l}\text { Delivered to } \\
\text { all parties }\end{array}$ & PE13 & $\begin{array}{l}\text { Training is obliged to be delivered to all parties, including } \\
\text { program, mechanism, material. }\end{array}$ & $\begin{array}{l}\text { Mandatory training is delivered to all parties involved, } \\
\text { including programs, mechanisms and materials. }\end{array}$ \\
\hline & & 14 & $\begin{array}{l}\text { Users } \\
\text { adaptation to } \\
\text { new process }\end{array}$ & PE14 & $\begin{array}{l}\text { Users can adapt to new processes from taking ERP } \\
\text { implementation training. }\end{array}$ & $\begin{array}{l}\text { Users can adapt well to the new process from taking ERP } \\
\text { implementation training. }\end{array}$ \\
\hline & & 15 & $\begin{array}{l}\text { Understand } \\
\text { the overall } \\
\text { concepts }\end{array}$ & PE15 & $\begin{array}{l}\text { Training goal to understand the overall concepts of the ERP } \\
\text { system. }\end{array}$ & $\begin{array}{l}\text { Training is useful for understanding the overall concept of } \\
\text { an ERP system. }\end{array}$ \\
\hline & & 16 & $\begin{array}{l}\text { Transfer } \\
\text { knowledge }\end{array}$ & PE16 & Transfer of knowledge to improve the quality of employees. & $\begin{array}{l}\text { Knowledge transfer for users to improve the quality of } \\
\text { employees is very necessary. }\end{array}$ \\
\hline \multirow{3}{*}{7} & \multirow{3}{*}{ Project team } & 17 & $\begin{array}{l}\text { Formed } \\
\text { project team }\end{array}$ & PE17 & Formed project team accordingly to project the scope. & $\begin{array}{l}\text { The project team must be formed according to the scope of } \\
\text { the ERP project. }\end{array}$ \\
\hline & & 18 & $\begin{array}{l}\text { Technical } \\
\text { expertise }\end{array}$ & PE18 & $\begin{array}{l}\text { Technical expertise, understanding for business processes, } \\
\text { processes knowledge, and ERP project experience. }\end{array}$ & $\begin{array}{l}\text { There is a project team that has technical expertise, } \\
\text { understanding of business processes, knowledge of ERP } \\
\text { processes, and ERP project experience. }\end{array}$ \\
\hline & & 19 & $\begin{array}{l}\text { Involved } \\
\text { Business } \\
\text { Process Owner }\end{array}$ & PE19 & $\begin{array}{l}\text { The involvement of a Business Process Owner in the project } \\
\text { team to map and manage business processes according to ERP } \\
\text { selected. }\end{array}$ & $\begin{array}{l}\text { The involvement of a Business Process Owner in the } \\
\text { project team to map and manage business processes } \\
\text { according to the ERP that will be implemented. }\end{array}$ \\
\hline \multirow{2}{*}{8} & \multirow{2}{*}{$\begin{array}{l}\text { Human } \\
\text { Resource } \\
\text { Management }\end{array}$} & 20 & $\begin{array}{l}\text { Available } \\
\text { Human } \\
\text { Resource }\end{array}$ & PE20 & $\begin{array}{l}\text { Ensure the availability of adequate Human Resources to } \\
\text { involved the ERP implementation process. }\end{array}$ & $\begin{array}{l}\text { Ensuring the availability of adequate human resources to } \\
\text { carry out the ERP implementation process. }\end{array}$ \\
\hline & & 21 & $\begin{array}{l}\text { Development } \\
\text { of competent } \\
\text { human }\end{array}$ & PE21 & $\begin{array}{l}\text { Development, utilization, and maintenance of competent } \\
\text { human force to achieve goals of an organization. }\end{array}$ & $\begin{array}{l}\text { The process of developing, utilizing, and maintaining } \\
\text { competent human resources to achieve organizational } \\
\text { goals in ERP project implementation. }\end{array}$ \\
\hline \multirow{2}{*}{9} & \multirow{2}{*}{$\begin{array}{l}\text { Clear roles } \\
\text { and } \\
\text { responsibi } \\
\text { lites }\end{array}$} & 22 & $\begin{array}{l}\text { Clear roles of } \\
\text { project }\end{array}$ & PE22 & $\begin{array}{l}\text { Clear roles of project stakeholders should be clearly defined, } \\
\text { fully documented and understood. }\end{array}$ & $\begin{array}{l}\text { The clear roles of project stakeholders must be clearly } \\
\text { defined, documented and fully understood by all teams } \\
\text { involved. }\end{array}$ \\
\hline & & 23 & $\begin{array}{l}\text { Clear } \\
\text { responsibilities } \\
\text { of project }\end{array}$ & PE23 & $\begin{array}{l}\text { Determination of the responsibilities of the tim involved in } \\
\text { ERP implementation. }\end{array}$ & $\begin{array}{l}\text { It is very important to determine the responsibility of the } \\
\text { team involved in ERP implementation. }\end{array}$ \\
\hline
\end{tabular}




\begin{tabular}{|c|c|c|c|c|c|c|}
\hline No & $\begin{array}{c}\text { Sub- } \\
\text { variables }\end{array}$ & No & Indicators & Code & Definition & Questionnaire statement \\
\hline \multirow{2}{*}{10} & \multirow{2}{*}{$\begin{array}{l}\text { Employee } \\
\text { /staf/user } \\
\text { involvement }\end{array}$} & 24 & $\begin{array}{l}\text { Employee } \\
\text { commitment }\end{array}$ & PE24 & Commitment of employees to implement ERP projects. & $\begin{array}{l}\text { Employee commitment in implementing ERP projects is } \\
\text { very necessary. }\end{array}$ \\
\hline & & 25 & $\begin{array}{l}\text { Employee } \\
\text { involvement }\end{array}$ & PE25 & $\begin{array}{l}\text { Employees are actively involved in the process of ERP } \\
\text { implementation stages. }\end{array}$ & $\begin{array}{l}\text { Employees are actively involved in participating in ERP } \\
\text { implementation activities. }\end{array}$ \\
\hline \multirow{6}{*}{11} & \multirow{6}{*}{$\begin{array}{l}\text { Shared } \\
\text { values }\end{array}$} & \multirow{3}{*}{26} & \multirow{3}{*}{$\begin{array}{l}\text { Project } \\
\text { champion }\end{array}$} & OG26 & $\begin{array}{l}\text { Project champion is a reliable person and trusted to regarding } \\
\text { implementation. }\end{array}$ & $\begin{array}{l}\text { Project champions are needed in ERP implementation, } \\
\text { because project champions are people who can be relied on } \\
\text { and trusted in ERP implementation activities. }\end{array}$ \\
\hline & & & & OG27 & $\begin{array}{l}\text { Project champion can ensure implementation processes run or } \\
\text { the possibility of project success. }\end{array}$ & $\begin{array}{l}\text { The project champion is needed to ensure the } \\
\text { implementation process runs well and also determines the } \\
\text { success of the ERP project. }\end{array}$ \\
\hline & & & & OG28 & $\begin{array}{l}\text { Project champion in an ERP implementation is fundamental in } \\
\text { implementation. }\end{array}$ & Project champion is fundamental in ERP implementation. \\
\hline & & 27 & $\begin{array}{l}\text { Shared } \\
\text { beliefs }\end{array}$ & OG29 & Belief to benefits of using ERP in organizations. & $\begin{array}{l}\text { All parties involved must have confidence in the benefits } \\
\text { of using ERP in the organization. }\end{array}$ \\
\hline & & \multirow{2}{*}{28} & \multirow{2}{*}{$\begin{array}{l}\text { Cross } \\
\text { functional } \\
\text { support }\end{array}$} & OG30 & Get support all function of organization. & $\begin{array}{l}\text { Support from all organizational functions in achieving } \\
\text { successful ERP implementation is needed. }\end{array}$ \\
\hline & & & & OG31 & Cross department cooperation. & $\begin{array}{l}\text { Cross-departmental collaboration is essential in achieving } \\
\text { a successful ERP implementation. }\end{array}$ \\
\hline \multirow{8}{*}{12} & \multirow{8}{*}{$\begin{array}{c}\text { Project } \\
\text { Management }\end{array}$} & \multirow{5}{*}{29} & \multirow{5}{*}{$\begin{array}{c}\text { Measurement } \\
\text { of } \\
\text { performance } \\
\text { specific, } \\
\text { measurable, } \\
\text { achievable, } \\
\text { relevant, time } \\
\text { bound }\end{array}$} & OG32 & $\begin{array}{l}\text { Performance measurement of ERP projects specifically in the } \\
\text { planning, implementation, and post-ERP implementation } \\
\text { processes. }\end{array}$ & $\begin{array}{l}\text { Specific ERP project performance measurement in the } \\
\text { planning, implementation, and post-ERP implementation } \\
\text { processes is essential. }\end{array}$ \\
\hline & & & & OG33 & $\begin{array}{l}\text { Performance measurement of ERP projects that the measurable } \\
\text { results of each stage of implementation. }\end{array}$ & $\begin{array}{l}\text { Measurable ERP project performance measurement at each } \\
\text { stage of ERP implementation is needed }\end{array}$ \\
\hline & & & & OG34 & $\begin{array}{l}\text { Performance measurement of ERP projects that the ERP } \\
\text { implementation is achieved. }\end{array}$ & $\begin{array}{l}\text { ERP project performance measurement that pays close } \\
\text { attention to the target of achieving ERP implementation } \\
\text { must be considered. }\end{array}$ \\
\hline & & & & OG35 & $\begin{array}{l}\text { Performance measurement of ERP projects that the relevant } \\
\text { results according to the company's vision and mission. }\end{array}$ & $\begin{array}{l}\text { ERP project performance measurement must pay attention } \\
\text { to the results that are relevant to the company's vision and } \\
\text { mission. }\end{array}$ \\
\hline & & & & OG36 & $\begin{array}{l}\text { Performance measurement of ERP projects that the } \\
\text { performance of the ERP project in accordance with a } \\
\text { predetermined target time. }\end{array}$ & $\begin{array}{l}\text { ERP project performance measurement must be in } \\
\text { accordance with a predetermined time schedule. }\end{array}$ \\
\hline & & \multirow[t]{2}{*}{30} & \multirow{2}{*}{$\begin{array}{l}\text { Monitoring of } \\
\text { performance }\end{array}$} & OG37 & Focused on customer need. & $\begin{array}{l}\text { ERP project performance measurement results should } \\
\text { focus on customer needs. }\end{array}$ \\
\hline & & & & OG38 & Controlling for implementation schedule. & $\begin{array}{l}\text { The performance control process is indispensable in ERP } \\
\text { implementation. }\end{array}$ \\
\hline & & 31 & $\begin{array}{c}\text { IT } \\
\text { Governance } \\
\end{array}$ & OG39 & Focus on IT governance with concerned to information quality. & $\begin{array}{l}\text { IT governance must pay attention to the quality of } \\
\text { information generated by ERP. }\end{array}$ \\
\hline \multirow{2}{*}{13} & \multirow{2}{*}{$\begin{array}{l}\text { Knowledge } \\
\text { Management }\end{array}$} & 32 & $\begin{array}{l}\text { Knowledge } \\
\text { sharing } \\
\text { process }\end{array}$ & OG40 & $\begin{array}{l}\text { Knowledge sharing process can greatly improve employees' } \\
\text { ability to learn and manage knowledge. }\end{array}$ & $\begin{array}{l}\text { The process of knowledge sharing is needed in an effort to } \\
\text { improve employee learning skills and manage their } \\
\text { knowledge. }\end{array}$ \\
\hline & & 33 & $\begin{array}{l}\text { Data and } \\
\text { information } \\
\text { standarized }\end{array}$ & OG41 & Ensure information standarized in all business operations. & $\begin{array}{l}\text { Data and information standarizedon all business operations } \\
\text { supports the use of ERP. }\end{array}$ \\
\hline \multirow{5}{*}{14} & \multirow{5}{*}{$\begin{array}{l}\text { Organizatio } \\
\text { nal structure }\end{array}$} & 34 & Centralization & OG42 & $\begin{array}{l}\text { Activities of an organisation, planning and decision-making are } \\
\text { controlled by the top management and project manager. }\end{array}$ & $\begin{array}{l}\text { Planning and decision-making activities that are controlled } \\
\text { by top management and project managers are required in } \\
\text { ERP projects. }\end{array}$ \\
\hline & & 35 & Specialization & OG43 & $\begin{array}{l}\text { Specialization is a business strategy that focuses on specialized } \\
\text { production for increasing productivity with ERP use. }\end{array}$ & $\begin{array}{l}\text { A business strategy that focuses on specialized production } \\
\text { is needed to increase productivity with the use of ERP. }\end{array}$ \\
\hline & & 36 & Formalization & OG44 & $\begin{array}{l}\text { Formalization as a process to define procedures, } \\
\text { standardization processes, responsibilities, and completely } \\
\text { documented. }\end{array}$ & $\begin{array}{l}\text { Organizational formalization is needed in ERP } \\
\text { implementation as a process in determining procedures, } \\
\text { standardizing work processes, and fully documented } \\
\text { responsibilities. }\end{array}$ \\
\hline & & 37 & $\begin{array}{l}\text { Size of } \\
\text { organization }\end{array}$ & OG45 & $\begin{array}{l}\text { The success of ERP projects may be impacted by organization } \\
\text { size. }\end{array}$ & $\begin{array}{l}\text { The size of the organization affects the success of an ERP } \\
\text { project. }\end{array}$ \\
\hline & & 38 & CIO position & OG46 & $\begin{array}{l}\text { CIO's role is to determine the alignment of business and } \\
\text { technology, ensure the availability, accuracy, accuracy and } \\
\text { security of information as needed to achieve the organizational } \\
\text { goals. }\end{array}$ & $\begin{array}{l}\text { The role of the Chief Information Officer (CIO) is needed } \\
\text { to determine the alignment of business and technology, } \\
\text { ensuring the availability, accuracy, accuracy, and security } \\
\text { of information according to management needs to achieve } \\
\text { organizational goals. }\end{array}$ \\
\hline & & \multirow[b]{2}{*}{39} & \multirow{2}{*}{$\begin{array}{l}\text { Top } \\
\text { management } \\
\text { commitment }\end{array}$} & OG47 & $\begin{array}{l}\text { Involved in every step of ERP project, monitor the progress } \\
\text { ERP. }\end{array}$ & $\begin{array}{l}\text { Top management must be involved in every process and } \\
\text { monitor the progress of the ERP project. }\end{array}$ \\
\hline & & & & OG48 & $\begin{array}{l}\text { Focusing on top management's commitment and willingness to } \\
\text { provide sufficient resources. }\end{array}$ & $\begin{array}{l}\text { Top management commitment is needed to provide } \\
\text { adequate resources and achieve a successful ERP } \\
\text { implementation. }\end{array}$ \\
\hline
\end{tabular}




\begin{tabular}{|c|c|c|c|c|c|c|}
\hline No & $\begin{array}{c}\text { Sub- } \\
\text { variables }\end{array}$ & No & Indicators & Code & Definition & Questionnaire statement \\
\hline \multirow{5}{*}{15} & \multirow{5}{*}{$\begin{array}{l}\text { Organizati } \\
\text { onal style }\end{array}$} & \multirow[b]{2}{*}{40} & \multirow[b]{2}{*}{ Communication } & OG49 & $\begin{array}{l}\text { Communicate all activities in the ERP implementation process } \\
\text { to all parties involved. }\end{array}$ & $\begin{array}{l}\text { Communicating all activities in the ERP implementation } \\
\text { process to all parties involved is very important. }\end{array}$ \\
\hline & & & & OG50 & $\begin{array}{l}\text { Sign off as proof of the communication and agreement on } \\
\text { project work. }\end{array}$ & $\begin{array}{l}\text { Sign off as proof of communication and agreement on } \\
\text { ERP project work must be approved by the parties } \\
\text { involved. }\end{array}$ \\
\hline & & 41 & $\begin{array}{l}\text { Organizational } \\
\text { culture }\end{array}$ & OG51 & $\begin{array}{l}\text { Organizational culture determines the right way to attitude and } \\
\text { make changes, including with regard to ERP implementation. }\end{array}$ & $\begin{array}{l}\text { Organizational culture determines the right way to behave } \\
\text { and make changes in ERP implementation. }\end{array}$ \\
\hline & & \multirow[b]{2}{*}{42} & \multirow[b]{2}{*}{$\begin{array}{l}\text { Vision and } \\
\text { mission }\end{array}$} & OG52 & $\begin{array}{l}\text { The clear of vision and mission as a guide ERP } \\
\text { implementation. }\end{array}$ & $\begin{array}{l}\text { A clear organizational vision and mission guides the } \\
\text { implementation of ERP implementation. }\end{array}$ \\
\hline & & & & OG53 & $\begin{array}{l}\text { A clear vision and mission must be revealed and communicated } \\
\text { into an important part that will support the ERP project. }\end{array}$ & $\begin{array}{l}\text { A clear organizational vision and mission must be revealed } \\
\text { and communicated to all parties involved to support the } \\
\text { implementation of the ERP project. }\end{array}$ \\
\hline \multirow{7}{*}{16} & \multirow{7}{*}{$\begin{array}{l}\text { Organizati } \\
\text { onal strategy }\end{array}$} & \multirow[t]{2}{*}{43} & \multirow[t]{2}{*}{$\begin{array}{l}\text { Goals and } \\
\text { objectives }\end{array}$} & OG54 & $\begin{array}{l}\text { Identification of measurable goals, the formation of the project } \\
\text { organization, and the motivation of the project team. }\end{array}$ & $\begin{array}{l}\text { The process of identifying measurable goals, establishing a } \\
\text { project organization, and the motivation of the ERP project } \\
\text { team are important factors in supporting ERP } \\
\text { implementation. }\end{array}$ \\
\hline & & & & OG55 & $\begin{array}{l}\text { Define and must be communicated effectively among } \\
\text { stakeholders involved. }\end{array}$ & $\begin{array}{l}\text { Project objectives and objectivity must be defined and } \\
\text { communicated effectively to the stakeholders involved. }\end{array}$ \\
\hline & & \multirow{5}{*}{44} & \multirow{5}{*}{$\begin{array}{l}\text { Project } \\
\text { planning } \\
\text { (scope, time, } \\
\text { budget, risk, } \\
\text { other resources) }\end{array}$} & OG56 & Determine the scope of the ERP project. & $\begin{array}{l}\text { Determination of a clear ERP project scope will determine } \\
\text { the success of ERP implementation. }\end{array}$ \\
\hline & & & & OG57 & $\begin{array}{l}\text { Confirming the ERP project for determine target of go live } \\
\text { time. }\end{array}$ & $\begin{array}{l}\text { All ERP project activities must be confirmed with all } \\
\text { parties involved in order to determine the target time to go } \\
\text { live. }\end{array}$ \\
\hline & & & & OG58 & $\begin{array}{l}\text { Budget usage needs to be controlled rigorously throughout the } \\
\text { ERP implementation. }\end{array}$ & $\begin{array}{l}\text { Budget usage needs to be strictly controlled during ERP } \\
\text { implementation. }\end{array}$ \\
\hline & & & & OG59 & $\begin{array}{l}\text { Project planning implementation can reduce the risk for the } \\
\text { failure. }\end{array}$ & $\begin{array}{l}\text { The implementation of project planning can reduce the risk } \\
\text { of failure in ERP implementation. }\end{array}$ \\
\hline & & & & OG60 & $\begin{array}{l}\text { Project planning implementation requires the availability of } \\
\text { complete resources. }\end{array}$ & $\begin{array}{l}\text { ERP implementation project planning must have complete } \\
\text { resource availability. }\end{array}$ \\
\hline \multirow[t]{2}{*}{17} & $\begin{array}{l}\text { System } \\
\text { rollout }\end{array}$ & 45 & Rollout system & TH61 & $\begin{array}{l}\text { Rollout system is a structured set of processes to anticipate } \\
\text { events that cause ERP implementation setbacks. }\end{array}$ & $\begin{array}{l}\text { A system rollout function to anticipate things that cause } \\
\text { ERP implementation setbacks must be available. }\end{array}$ \\
\hline & configuration & 46 & $\begin{array}{l}\text { Configuration } \\
\text { system }\end{array}$ & TH62 & $\begin{array}{l}\text { A configuration refers to the hardware and software that greatly } \\
\text { affect ERP implementation success. }\end{array}$ & $\begin{array}{l}\text { Correct configuration of hardware and software affects the } \\
\text { success of ERP implementation. }\end{array}$ \\
\hline \multirow{6}{*}{18} & \multirow{6}{*}{$\begin{array}{l}\text { System } \\
\text { integration }\end{array}$} & \multirow[b]{2}{*}{47} & \multirow{2}{*}{$\begin{array}{l}\text { IT } \\
\text { infrastructure }\end{array}$} & TH63 & $\begin{array}{l}\text { Determine the software, hardware, and network infrastructure } \\
\text { that will be needed for the ERP system. }\end{array}$ & $\begin{array}{l}\text { Determining the correct software, hardware and network } \\
\text { infrastructure is needed in ERP implementation. }\end{array}$ \\
\hline & & & & TH64 & $\begin{array}{l}\text { Adequate IT infrastructure, hardware and networking for ERP } \\
\text { implementation. }\end{array}$ & $\begin{array}{l}\text { It is necessary to conduct an assessment of the adequacy of } \\
\text { IT infrastructure, hardware and networks before } \\
\text { implementing ERP. }\end{array}$ \\
\hline & & \multirow{2}{*}{48} & \multirow{2}{*}{$\begin{array}{l}\text { Processes } \\
\text { improvement }\end{array}$} & TH65 & $\begin{array}{l}\text { Process improvements need to be identified before the } \\
\text { implementation of ERP. }\end{array}$ & $\begin{array}{l}\text { Identification of process improvements must be done prior } \\
\text { to ERP implementation. }\end{array}$ \\
\hline & & & & TH66 & $\begin{array}{l}\text { Information usable that provides benefits that support decision } \\
\text { making related to ERP projects. }\end{array}$ & $\begin{array}{l}\text { Useful information is needed to support decision making } \\
\text { in ERP projects. }\end{array}$ \\
\hline & & \multirow{2}{*}{49} & \multirow{2}{*}{$\begin{array}{l}\text { Data } \\
\text { management }\end{array}$} & TH67 & $\begin{array}{l}\text { Data comprehensive that supports decision making related to } \\
\text { ERP projects. }\end{array}$ & $\begin{array}{l}\text { Complete data comprehensively supports decision making } \\
\text { in ERP projects. }\end{array}$ \\
\hline & & & & TH68 & $\begin{array}{l}\text { Data availability as needed to support decision making related } \\
\text { to ERP projects. }\end{array}$ & $\begin{array}{l}\text { The availability of data that is suitable for management } \\
\text { needs for decision making in ERP projects is needed. }\end{array}$ \\
\hline \multirow{2}{*}{19} & \multirow{2}{*}{$\begin{array}{l}\text { IT structure } \\
\text { and legacy } \\
\text { systems }\end{array}$} & 50 & IT structure & TH69 & $\begin{array}{l}\text { IT team structure to coordinate ERP project activities from } \\
\text { planning to post-go live. }\end{array}$ & $\begin{array}{l}\text { Good IT team structure to coordinate ERP project } \\
\text { activities from planning to post-go live. }\end{array}$ \\
\hline & & 51 & Legacy systems & TH70 & Good integration with legacy systems. & $\begin{array}{l}\text { Integration with old systems in ERP implementation must } \\
\text { be done well. }\end{array}$ \\
\hline \multirow[t]{2}{*}{20} & \multirow{2}{*}{$\begin{array}{l}\text { Technology } \\
\text { selection \& } \\
\text { adaptation } \\
\text { (Technolo } \\
\text { gical } \\
\text { readiness) }\end{array}$} & 52 & $\begin{array}{l}\text { Technology } \\
\text { selection }\end{array}$ & TH71 & $\begin{array}{l}\text { The company's readiness in selection, providing, and } \\
\text { implementing technology that supports business strategies. }\end{array}$ & $\begin{array}{l}\text { An assessment of the company's readiness in selecting, } \\
\text { providing, and implementing technology that supports } \\
\text { business strategies must be carried out. }\end{array}$ \\
\hline & & 53 & $\begin{array}{l}\text { Technology } \\
\text { adaptation }\end{array}$ & TH72 & $\begin{array}{l}\text { Adaptation of technology used to support optimal ERP } \\
\text { implementation strategy. }\end{array}$ & $\begin{array}{l}\text { Adaptation of the technology used to support the ERP } \\
\text { implementation strategy is needed. }\end{array}$ \\
\hline \multirow[t]{2}{*}{21} & \multirow{2}{*}{$\begin{array}{l}\text { System } \\
\text { acceptance } \\
\text { and usage }\end{array}$} & 54 & $\begin{array}{l}\text { System } \\
\text { acceptance }\end{array}$ & TH73 & $\begin{array}{l}\text { Acceptance of users to use ERP in completing work will } \\
\text { increase the work more effective and efficient. }\end{array}$ & $\begin{array}{l}\text { Acceptance of users to use ERP in completing work and } \\
\text { improving a more effective way of working is very } \\
\text { important }\end{array}$ \\
\hline & & 55 & System usage & TH74 & $\begin{array}{l}\text { The use of information technology can improve the } \\
\text { performance of the organization. }\end{array}$ & $\begin{array}{l}\text { The optimal use of information technology can improve } \\
\text { overall organizational performance. }\end{array}$ \\
\hline \multirow[b]{2}{*}{22} & \multirow{2}{*}{$\begin{array}{l}\text { Trouble } \\
\text { shooting }\end{array}$} & 56 & $\begin{array}{l}\text { Helpdesk } \\
\text { system }\end{array}$ & TH75 & $\begin{array}{l}\text { The available of a helap system to help users in providing fast } \\
\text { response in troubleshooting related to ERP use. }\end{array}$ & $\begin{array}{l}\text { The availability of a helpdesk system will help users } \\
\text { quickly solve problems related to the use of ERP. }\end{array}$ \\
\hline & & 57 & Service to users & TH76 & $\begin{array}{l}\text { The available of an IT team to serve users in providing } \\
\text { troubleshooting related to ERP use. }\end{array}$ & $\begin{array}{l}\text { The availability of an IT team that provides services for } \\
\text { users and provides solutions to problems related to the use } \\
\text { of ERP is very much needed. }\end{array}$ \\
\hline
\end{tabular}


S.F. Wijaya et al. / Advances in Science, Technology and Engineering Systems Journal Vol. 6, No. 1, 538-549 (2021)

\begin{tabular}{|c|c|c|c|c|c|c|}
\hline No & $\begin{array}{c}\text { Sub- } \\
\text { variables }\end{array}$ & No & Indicators & Code & Definition & Questionnaire statement \\
\hline \multirow{2}{*}{23} & \multirow{2}{*}{$\begin{array}{l}\text { External } \\
\text { consultant / } \\
\text { expertise }\end{array}$} & 58 & $\begin{array}{l}\text { Functional } \\
\text { consultant }\end{array}$ & TH77 & $\begin{array}{l}\text { Analyzes running business processes and provides directions } \\
\text { for following ERP business processes that can be implemented. }\end{array}$ & $\begin{array}{l}\text { Consultants can analyze running business processes and } \\
\text { provide directions for following ERP business processes } \\
\text { so that they can be implemented properly. }\end{array}$ \\
\hline & & 59 & $\begin{array}{l}\text { Technical } \\
\text { consultant }\end{array}$ & TH78 & $\begin{array}{l}\text { Consultant expertise in providing directions and solutions for } \\
\text { technical matters related to ERP implementation. }\end{array}$ & $\begin{array}{l}\text { Consultants can provide direction and solutions for } \\
\text { technical matters related to ERP implementation. }\end{array}$ \\
\hline \multirow{2}{*}{24} & \multirow{2}{*}{$\begin{array}{l}\text { Vendor } \\
\text { relationship } \\
\text { and support }\end{array}$} & 60 & $\begin{array}{l}\text { Vendor } \\
\text { engagement }\end{array}$ & TH79 & $\begin{array}{l}\text { Relationships and angagement with vendors will speed up } \\
\text { problem solving related to the ERP implementation process. }\end{array}$ & $\begin{array}{l}\text { Relationships and agreements with vendors can speed up } \\
\text { problem solving related to the ERP implementation } \\
\text { process. }\end{array}$ \\
\hline & & 61 & $\begin{array}{l}\text { Supply } \\
\text { Chain } \\
\text { Management }\end{array}$ & TH80 & $\begin{array}{l}\text { Network of interconnected department for fulfilling the } \\
\text { material required by the other departments or by the customers. }\end{array}$ & $\begin{array}{l}\text { Inter-departmental networks that are interconnected to } \\
\text { meet material requirements for other departments or for } \\
\text { customers are very necessary in ERP. }\end{array}$ \\
\hline
\end{tabular}

The characteristic of CMMI is initial, defined, managed, measured, and optimized [19]. Initial: Unpredicable, uncontrolled, no-automation. Defined: Some shared decision-making. Managed: Collaboration, analyze trend, and portfolios. Measured: Central automated process, standardized across the organization. Optimized: Focused on continuous improvement, stability provides a platform for agility and innovation. The related between characteristic of maturity level with readiness of ERP readiness assessment module, which can be seen in Figure 1.

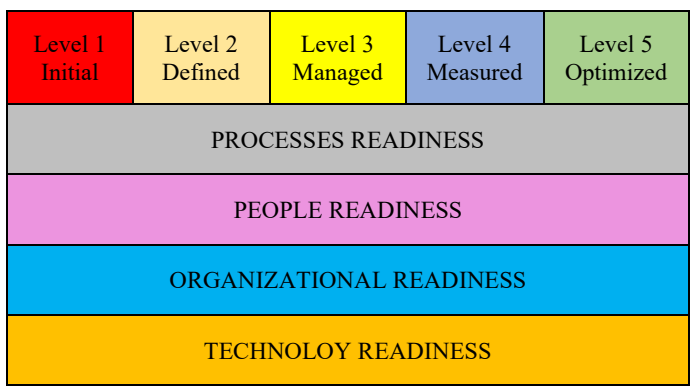

Figure 1: ERP Readiness Assessment model

Based on these main variables (processes readiness, people readiness, organizational readiness, and technology readiness), it is derived into 24 sub-variables and 61 indicators. The grouping of processes readiness variables is derived into 3 sub-variables and 7 indicators can be seen in Figure 2 .

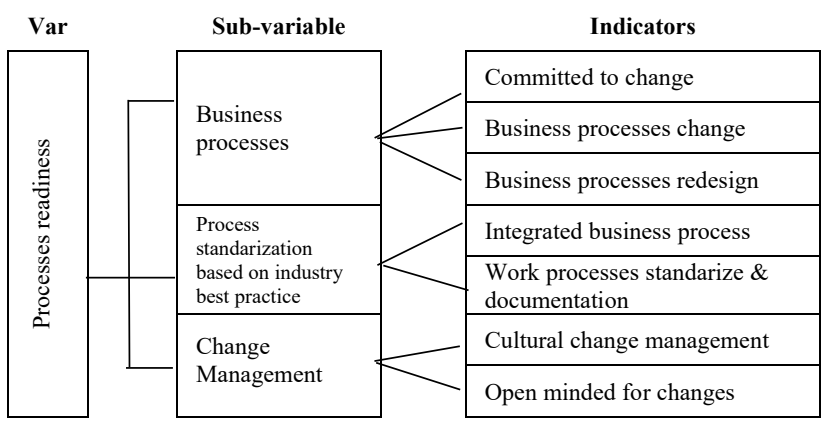

Figure 2: Processes readiness of ERP Readiness Assessment

The grouping of people readiness variables is derived into 7 sub-variables and 18 indicators can be seen in Figure 3.

The grouping of organizational readiness variables is derived into 9 sub-variables and 25 indicators can be seen in Figure 4.

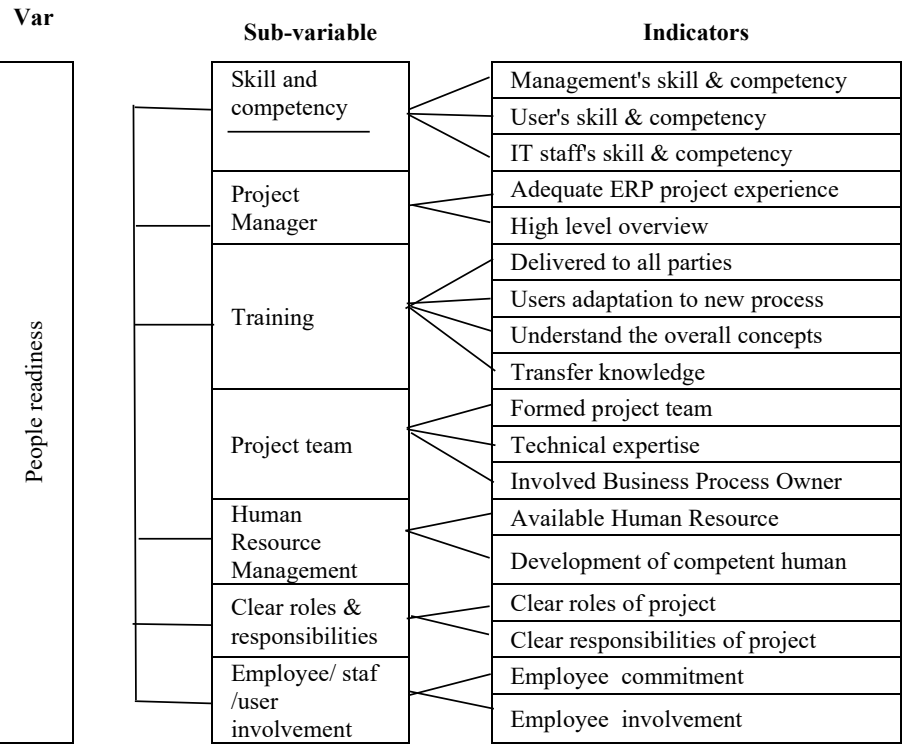

Figure 3: People readiness of ERP Readiness Assessment

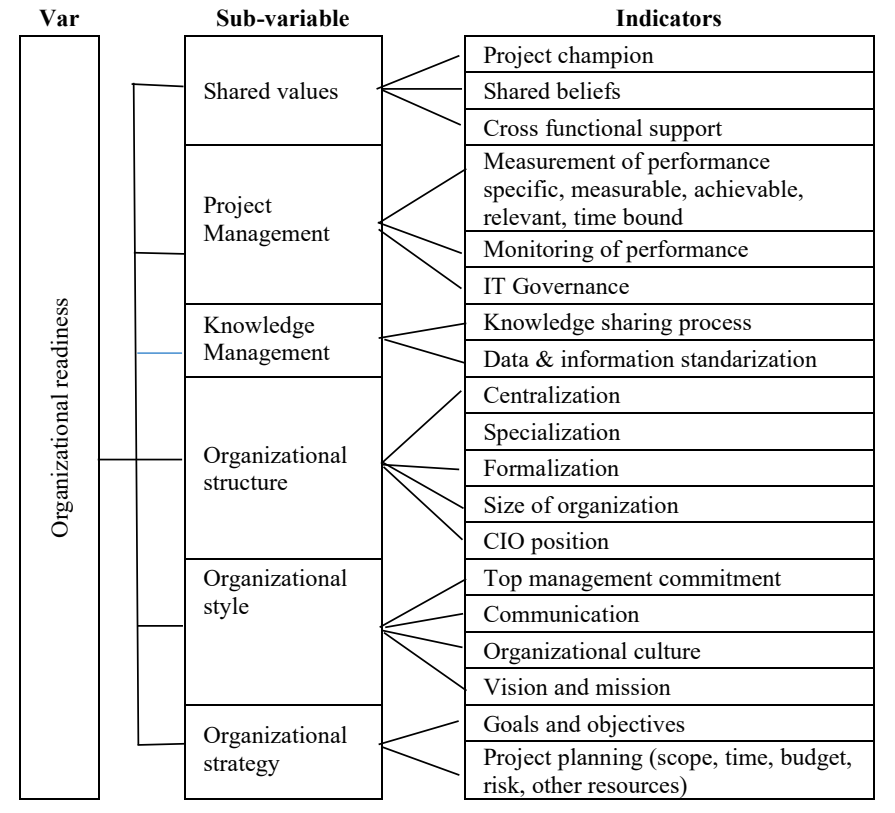

Figure 4: Organizational readiness of ERP Readiness Assessment

The grouping of technology readiness variables is derived into 8 sub-variables and 17 indicators. The grouping of technology 
readiness for each sub-variables and indicator can be seen in Figure 5.

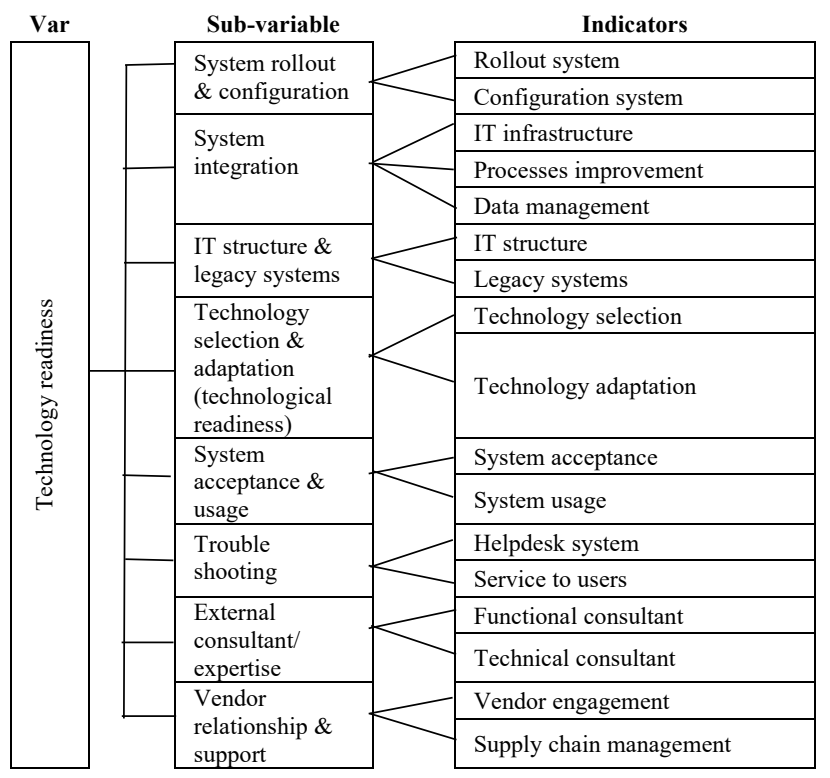

Figure 5: Technology readiness of ERP Readiness Assessment

\section{Result and discussion}

\subsection{Data processing of the questionnaires}

As a result of distributing questionnaires to respondents, Authors made a characteristics profile of respondents which can be seen in Table 2.

Table 2: Characteristics profile of respondents

\begin{tabular}{|c|c|c|c|}
\hline \multicolumn{2}{|c|}{ Respondent profile } & Frequency & $\%$ \\
\hline Gender & $\begin{array}{l}\text { Male } \\
\text { Female }\end{array}$ & $\begin{array}{l}96 \\
35\end{array}$ & $\begin{array}{l}73 \% \\
27 \%\end{array}$ \\
\hline & & 131 & $100 \%$ \\
\hline Age & $\begin{array}{l}\text { 20-30 years } \\
31-40 \text { years } \\
41-50 \text { years } \\
>51 \text { years }\end{array}$ & $\begin{array}{l}38 \\
34 \\
36 \\
23 \\
\end{array}$ & $\begin{array}{l}29 \% \\
26 \% \\
27 \% \\
18 \% \\
\end{array}$ \\
\hline $\begin{array}{l}\text { Level of } \\
\text { education }\end{array}$ & $\begin{array}{l}\text { Strata-1 (bachelor) } \\
\text { Strata-2 } \\
\text { (undergraduate) } \\
\text { Strata-3 (doctoral) }\end{array}$ & $\begin{array}{r}90 \\
36 \\
5\end{array}$ & $\begin{array}{r}69 \% \\
27 \% \\
4 \%\end{array}$ \\
\hline $\begin{array}{l}\text { Work } \\
\text { experience }\end{array}$ & $\begin{array}{l}1-2 \text { years } \\
2-3 \text { years } \\
3-4 \text { years } \\
>4 \text { years }\end{array}$ & $\begin{array}{r}34 \\
6 \\
16 \\
75\end{array}$ & $\begin{array}{r}26 \% \\
5 \% \\
12 \% \\
57 \%\end{array}$ \\
\hline $\begin{array}{l}\text { Educational } \\
\text { background }\end{array}$ & $\begin{array}{l}\text { Information } \\
\text { technology } \\
\text { Finance/Accounting } \\
\text { Marketing } \\
\text { Production } \\
\text { Others }\end{array}$ & $\begin{array}{r}68 \\
43 \\
5 \\
3 \\
12\end{array}$ & $\begin{array}{r}52 \% \\
33 \% \\
4 \% \\
2 \% \\
9 \% \\
\end{array}$ \\
\hline Level & $\begin{array}{l}\text { Staff } \\
\text { Manager } \\
\text { Director }\end{array}$ & $\begin{array}{l}57 \\
60 \\
14\end{array}$ & $\begin{array}{l}44 \% \\
46 \% \\
11 \%\end{array}$ \\
\hline $\begin{array}{l}\text { Industry } \\
\text { type }\end{array}$ & $\begin{array}{l}\text { Textile industry } \\
\text { Garment industry } \\
\text { Consultant }\end{array}$ & $\begin{array}{l}67 \\
39 \\
25\end{array}$ & $\begin{array}{l}51 \% \\
30 \% \\
19 \%\end{array}$ \\
\hline
\end{tabular}

The authors grouping indicators the data collection to organizational readiness in ERP implementation, by determining the following components to Gender: The authors included gender components because it can influence in emotions in decision making in the data collection according the character of the respondents. Age: The authors included age components because it can influence decision making in the data collection according to work experience from respondents. Work experience: Authors included work experience components because it can influence maturity in decision making in the data collection according the work experience using ERP from respondents. Educational background: The authors included educational background components in the data collection because it can affect the level of maturity in decision making. Position: Authors included a position components because it can influences the maturity level in decision making. Industry type: Authors included industry type components in data collection because it can be comparison of the data processing result. The authors forward to test of 61 indicators using the multivariate Principal Component Analysis (PCA) statistical approach using R software, which meets the following requirement, namely the $\mathrm{p}$ value must be less than 0.05, and the Measure of Sampling Adequacy(MSA) value must be greater than 0.5 . The results of PCA data processing using software $\mathrm{R}$ show that Kaiser-Meyer Olkin $(\mathrm{KMO})=0.866$, where all indicators have "KMO $>0.5$ ", so it can be interpreted that the KMO value has requirement. The results of data processing from the PCA test show that 61 indicators from into 24 Release Candidate (RC) with the sum of the squared loadings (SS Loadings) achieve contributes 83\% cumulative variable. The SS loading value is the result of automatic calculation from the $\mathrm{R}$ software. Based on $\mathrm{RC}$ results of PCA data processing using R software by calculation for more than one of eigen value (SS Loading $>1$ ) achieved at a cumulative variable $83 \%$ with $\mathrm{RC}$ is 24 , this is the optimum value calculated achieve cumulative proportion $100 \%$. The release Candidate result can be seen in Table 3 .

Table 3: Release Candidate results

\begin{tabular}{|c|l|r|r|r|r|r|}
\hline No & RC & $\begin{array}{c}\text { SS } \\
\text { Loading }\end{array}$ & $\begin{array}{c}\text { Proportion } \\
\text { variable }\end{array}$ & $\begin{array}{c}\text { Cumulative } \\
\text { variable }\end{array}$ & $\begin{array}{c}\text { Proportion } \\
\text { Explained }\end{array}$ & $\begin{array}{c}\text { Cumulative } \\
\text { Proportion }\end{array}$ \\
\hline 1 & RC1 & 5.73 & $7 \%$ & $7 \%$ & $10,00 \%$ & $10 \%$ \\
\hline 2 & RC21 & 4.68 & $6 \%$ & $13 \%$ & $7,00 \%$ & $17 \%$ \\
\hline 3 & RC4 & 4.62 & $6 \%$ & $19 \%$ & $7,00 \%$ & $24 \%$ \\
\hline 4 & RC2 & 4.06 & $5 \%$ & $24 \%$ & $6,00 \%$ & $30 \%$ \\
\hline 5 & RC24 & 3.53 & $4 \%$ & $28 \%$ & $5,00 \%$ & $35 \%$ \\
\hline 6 & RC13 & 3.43 & $4 \%$ & $32 \%$ & $5,00 \%$ & $40 \%$ \\
\hline 7 & RC22 & 3.37 & $4 \%$ & $36 \%$ & $5,00 \%$ & $45 \%$ \\
\hline 8 & RC3 & 2.86 & $4 \%$ & $40 \%$ & $4,00 \%$ & $49 \%$ \\
\hline 9 & RC7 & 2.85 & $4 \%$ & $44 \%$ & $4,00 \%$ & $53 \%$ \\
\hline 10 & RC19 & 2.82 & $4 \%$ & $48 \%$ & $4,00 \%$ & $57 \%$ \\
\hline 11 & RC17 & 2.66 & $3 \%$ & $51 \%$ & $4,00 \%$ & $61 \%$ \\
\hline 12 & RC15 & 2.63 & $3 \%$ & $54 \%$ & $4,00 \%$ & $65 \%$ \\
\hline 13 & RC5 & 2.46 & $3 \%$ & $57 \%$ & $4,00 \%$ & $69 \%$ \\
\hline 14 & RC9 & 2.45 & $3 \%$ & $60 \%$ & $4,00 \%$ & $73 \%$ \\
\hline 15 & RC10 & 2.30 & $3 \%$ & $63 \%$ & $3,00 \%$ & $76 \%$ \\
\hline 16 & RC16 & 2.21 & $3 \%$ & $66 \%$ & $3,00 \%$ & $79 \%$ \\
\hline 17 & RC8 & 2.16 & $3 \%$ & $69 \%$ & $3,00 \%$ & $82 \%$ \\
\hline 18 & RC12 & 2.11 & $3 \%$ & $72 \%$ & $3,00 \%$ & $85 \%$ \\
\hline 19 & RC6 & 1.96 & $2 \%$ & $74 \%$ & $3,00 \%$ & $88 \%$ \\
\hline 20 & RC20 & 1.86 & $2 \%$ & $76 \%$ & $3,00 \%$ & $91 \%$ \\
\hline 21 & RC23 & 1.77 & $2 \%$ & $78 \%$ & $3,00 \%$ & $94 \%$ \\
\hline 22 & RC11 & 1.54 & $2 \%$ & $80 \%$ & $2,00 \%$ & $96 \%$ \\
\hline 23 & RC18 & 1.52 & $2 \%$ & $82 \%$ & $2,00 \%$ & $98 \%$ \\
\hline 24 & RC14 & 1.05 & $1 \%$ & $83 \%$ & $2,00 \%$ & $100 \%$ \\
\hline S5 Lo & & & & \\
\hline
\end{tabular}

SS Loading is the sum of the squared loadings

$\mathrm{RC}$ is Release Candidate 
S.F. Wijaya et al. / Advances in Science, Technology and Engineering Systems Journal Vol. 6, No. 1, 538-549 (2021)

Based on the results of R software data processing for 24RC, the authors analyze for finding the highest value of each indicator, then the authors classify according to each of RC with create a new group for 24RC. The PCA result of data processing using R software can be seen in Table 4 .

Table 4: Principal Component Analysis

\begin{tabular}{|c|c|c|c|c|c|c|c|c|c|}
\hline $\mathrm{RC}$ & Indicator & $\mathrm{RC} 1$ & $\mathrm{RC} 2$ & $\mathrm{RC} 3$ & $\mathrm{RC4}$ & RC5 & RC6 & $\mathrm{RC7}$ & RC8 \\
\hline \multirow{7}{*}{$\mathrm{RCl}$} & OG26 & 0.80 & 0.10 & 0.06 & 0.17 & 0.15 & 0.05 & 0.12 & 0.14 \\
\hline & OG27 & 0.82 & 0.05 & 0.11 & 0.13 & 0.09 & 0.05 & 0.11 & 0.04 \\
\hline & OG28 & 0.72 & 0.03 & 0.06 & 0.20 & -0.10 & 0.15 & 0.06 & 0.11 \\
\hline & OG43 & 0.46 & 0.12 & 0.15 & 0.09 & -0.05 & -0.03 & 0.17 & 0.17 \\
\hline & PE22 & 0.41 & 0.39 & 0.04 & 0.18 & 0.13 & 0.05 & 0.06 & 0.10 \\
\hline & OG38 & 0.36 & 0.23 & 0.02 & 0.23 & -0.03 & 0.17 & 0.19 & 0.16 \\
\hline & TH61 & 0.34 & 0.07 & 0.34 & 0.23 & 0.03 & 0.04 & 0.03 & 0.03 \\
\hline \multirow{8}{*}{$\mathrm{RC} 2$} & PR06 & 0.11 & 0.4 & 0.13 & 0.12 & 0.40 & -0.11 & 0.03 & 0.21 \\
\hline & OG29 & 0.09 & 0.4 & 0.12 & 0.17 & -0.01 & 0.03 & 0.03 & 0.05 \\
\hline & OG30 & $0.0 \overline{-}$ & 0.79 & 0.14 & 0.10 & 0.05 & 0.16 & 0.01 & 0.12 \\
\hline & OG31 & 0.15 & 0.53 & 0.12 & 0.11 & 0.37 & -0.14 & 0.23 & 0.08 \\
\hline & OG32 & 0.34 & 0.43 & 0.09 & 0.18 & 0.14 & 0.2 & 0.27 & 0.01 \\
\hline & OG33 & 0.12 & 0.46 & 0.18 & 0.09 & 0.10 & 0.18 & 0.18 & 0.03 \\
\hline & OG34 & 0.29 & 0.45 & 0.15 & 0.30 & 0.04 & 0.16 & 0.07 & 0.03 \\
\hline & OG36 & 0.20 & 0.47 & 0.22 & 0.11 & 0.07 & 0.13 & 0.14 & 0.19 \\
\hline \multirow{2}{*}{ RC3 } & TH62 & 0.09 & 0.16 & 0.78 & 0.14 & 0.08 & 0.07 & 0.11 & 0.10 \\
\hline & TH63 & 0.13 & 0.10 & 0.68 & 0.25 & 0.11 & 0.20 & 0.23 & 0.06 \\
\hline \multirow{4}{*}{ RC4 } & TH74 & 0.02 & 0.09 & 0.3 & 0.5 & -0.01 & 0.10 & 0.34 & 0.22 \\
\hline & TH77 & 0.14 & 0.08 & 0.07 & 0.81 & 0.07 & -0.08 & 0.11 & 0.02 \\
\hline & TH78 & 0.22 & 0.08 & 0.16 & 0.82 & 0.12 & 0.03 & 0.08 & 0.05 \\
\hline & TH79 & 0.20 & 0.23 & 0.23 & 0.62 & -0.03 & 0.28 & $0.0 \overline{-}$ & 0.07 \\
\hline \multirow{3}{*}{ RC5 } & PR01 & 0.03 & 0.11 & 0.18 & 0.11 & 0.74 & 0.08 & 0.02 & 0.18 \\
\hline & PR04 & 0.36 & 0.16 & 0.02 & 0.02 & 0.49 & 0.07 & 0.09 & 0.05 \\
\hline & PR05 & 0.15 & 0.17 & 0.22 & 0.34 & 0.36 & 0.16 & 0.32 & 0.09 \\
\hline RC6 & OG58 & 0.13 & 0.15 & 0.16 & 0.05 & 0.05 & 0.81 & - & 0.01 \\
\hline \multirow{2}{*}{ RC7 } & TH75 & 0.25 & 0.11 & 0.23 & 0.12 & 0.06 & 0.07 & 0.69 & 0.05 \\
\hline & TH76 & 0.17 & 0.04 & 0.22 & 0.20 & - & -0.16 & 0.61 & 0.14 \\
\hline \multirow{3}{*}{ RC8 } & OG41 & 0.07 & 0.25 & 0.01 & 0.17 & 0.16 & 0.08 & 0.37 & 0.44 \\
\hline & OG42 & 0.04 & - & 0.12 & 0.09 & 0.11 & 0.04 & 0.21 & 0.56 \\
\hline & OG48 & 0.17 & 0.17 & 0.16 & 0.06 & 0.23 & -0.01 & 0.03 & 0.7 \\
\hline
\end{tabular}

\begin{tabular}{|c|c|c|c|c|c|c|c|c|c|}
\hline $\mathrm{RC}$ & Indicator & RC9 & $\mathrm{RC} 10$ & RC11 & $\mathrm{RC12}$ & $\mathrm{RC} 13$ & $\mathrm{RC} 14$ & RC15 & RC16 \\
\hline \multirow{3}{*}{ RC9 } & PR07 & 0.54 & 0.14 & 0.09 & 0.21 & 0.28 & $0.10^{-}$ & 0.01 & 0.09 \\
\hline & PE11 & 0.68 & 0.01 & 0.05 & 0.04 & 0.14 & 0.06 & 0.08 & 0.02 \\
\hline & PE12 & 0.5 & 0.19 & 0.11 & 0.07 & 0.02 & 0.17 & 0.19 & 0.27 \\
\hline $\mathrm{RC} 10$ & PE20 & 0.05 & 0.51 & 0.09 & 0.06 & 0.03 & 0.19 & 0.13 & 0.19 \\
\hline
\end{tabular}

\begin{tabular}{|c|c|c|c|c|c|c|c|c|c|}
\hline & PE21 & 0.11 & 0.62 & 0.11 & 0.16 & 0.21 & - & 0.14 & 0.12 \\
\hline & PE25 & 0.06 & 0.45 & 0.01 & 0.09 & $0.03^{-}$ & 0.09 & 0.03 & 0.16 \\
\hline $\mathrm{RC} 11$ & PE08 & 0.09 & 0.08 & 0.78 & 0.08 & 0.16 & 0.13 & 0.07 & 0.10 \\
\hline \multirow{2}{*}{$\mathrm{RC} 12$} & PR02 & 0.08 & 0.12 & 0.09 & 0.78 & 0.15 & 0.04 & 0.18 & \\
\hline & PR03 & 0.17 & $0.22^{-}$ & $0.1 \overline{0}$ & 0.47 & 0.18 & 0.1 & 0.03 & 0.14 \\
\hline \multirow{6}{*}{$\mathrm{RC} 13$} & OG49 & 0.08 & 0.23 & 0.17 & 0.08 & 0.54 & 0.01 & 0.26 & 0.10 \\
\hline & OG57 & 0.24 & 0.05 & 0.2 & - & 0.64 & 0.11 & 0.07 & 0.07 \\
\hline & OG60 & 0.19 & 0.17 & 0.06 & 0.1 & 0.39 & 0.02 & 0.17 & 0.28 \\
\hline & TH67 & 0.18 & 0.04 & 0.2 & 0.08 & 0.47 & 0.16 & 0.25 & 0.10 \\
\hline & TH68 & 0.08 & 0.11 & 0.03 & 0.16 & 0.57 & 0.22 & $0.10^{-}$ & 0.09 \\
\hline & TH73 & 0.02 & 0.13 & 0.06 & 0.1 & 0.45 & 0.1 & 0.31 & 0.06 \\
\hline $\mathrm{RC} 14$ & PE19 & 0.22 & 0.1 & 0.01 & 0.02 & 0.15 & 0.51 & 0.04 & 0.09 \\
\hline \multirow{3}{*}{$\mathrm{RC} 15$} & OG44 & 0.09 & 0.05 & 0.06 & 0.09 & 0.03 & 0.08 & 0.55 & 0.16 \\
\hline & OG45 & 0.15 & 0.19 & 0.1 & 0.24 & 0.24 & 0.15 & 0.35 & 0.10 \\
\hline & OG51 & 0.11 & - & 0.07 & $0.0 \overline{-}$ & 0.13 & $0 . \overline{7}$ & 0.69 & 0.07 \\
\hline \multirow{2}{*}{$\mathrm{RC} 16$} & PE23 & 0.17 & 0.21 & 0.1 & 0.2 & $0.04^{-}$ & 0.21 & 0.03 & 0.46 \\
\hline & PE24 & 0.01 & 0.04 & 0.14 & - & 0.10 & $0.0 \bar{r}^{-}$ & 0.05 & 0.81 \\
\hline
\end{tabular}

\begin{tabular}{|c|c|c|c|c|c|c|c|c|c|}
\hline $\mathrm{RC}$ & Indicator & $\mathrm{RC} 17$ & $\mathrm{RC} 18$ & $\mathrm{RC} 19$ & $\mathrm{RC} 20$ & $\mathrm{RC} 21$ & $\mathrm{RC} 22$ & $\mathrm{RC} 23$ & $\mathrm{RC} 24$ \\
\hline \multirow[t]{2}{*}{ RC17 } & OG46 & 0.65 & $0.10^{-}$ & 0.16 & 0.15 & 0.21 & 0.09 & 0.11 & 0.12 \\
\hline & OG47 & 0.79 & 0.15 & 0.04 & 0.04 & 0.12 & 0.13 & 0.01 & 0.09 \\
\hline \multirow[t]{2}{*}{$\mathrm{RC} 18$} & TH69 & 0.14 & 0.54 & 0.22 & 0.10 & 0.16 & 0.10 & 0.13 & 0.15 \\
\hline & TH72 & 0.04 & 0.47 & 0.36 & 0.06 & 0.21 & 0.12 & 0.02 & 0.18 \\
\hline \multirow[t]{4}{*}{ RC19 } & OG40 & 0.17 & 0.08 & 0.53 & 0.18 & 0.20 & 0.21 & 0.10 & 0.24 \\
\hline & OG56 & 0.06 & 0.21 & 0.39 & 0.10 & 0.07 & 0.25 & 0.08 & 0.37 \\
\hline & TH70 & 0.21 & 0.06 & 0.49 & 0.18 & 0.19 & 0.15 & 0.24 & 0.08 \\
\hline & TH71 & 0.03 & 0.09 & 0.75 & 0.05 & 0.17 & 0.06 & 0.05 & 0.17 \\
\hline \multirow[t]{2}{*}{ RC20 } & PE15 & 0.11 & 0.10 & 0.16 & 0.61 & 0.11 & 0.14 & 0.09 & 0.05 \\
\hline & PE13 & 0.02 & 0.09 & 0.26 & 0.43 & 0.13 & 0.10 & 0.30 & 0.24 \\
\hline \multirow[t]{6}{*}{$\mathrm{RC} 21$} & OG35 & 0.05 & 0.01 & 0.27 & 0.22 & 0.45 & 0.17 & 0.15 & 0.15 \\
\hline & OG37 & 0.04 & 0.02 & 0.10 & 0.40 & 0.49 & 0.25 & 0.13 & 0.03 \\
\hline & OG52 & 0.17 & 0.08 & 0.16 & - & 0.77 & 0.12 & 0.08 & 0.04 \\
\hline & OG53 & 0.08 & 0.10 & 0.12 & 0.06 & 0.80 & 0.11 & 0.01 & 0.17 \\
\hline & OG54 & 0.03 & 0.17 & 0.01 & - & 0.47 & 0.17 & 0.19 & 0.22 \\
\hline & OG55 & 0.18 & 0.07 & 0.22 & 0.09 & 0.37 & 0.11 & 0.11 & 0.08 \\
\hline \multirow[t]{6}{*}{ RC22 } & PE09 & 0.13 & 0.07 & 0.23 & 0.05 & 0.01 & 0.60 & 0.09 & 0.21 \\
\hline & PE16 & 0.08 & $\begin{array}{r}- \\
0.11\end{array}$ & 0.22 & 0.36 & 0.01 & 0.43 & 0.18 & 0.27 \\
\hline & PE17 & 0.18 & 0.12 & 0.04 & 0.09 & 0.28 & 0.67 & 0.14 & 0.05 \\
\hline & PE18 & 0.05 & 0.14 & 0.13 & 0.10 & 0.25 & 0.54 & 0.04 & 0.08 \\
\hline & OG50 & 0.20 & - & 0.02 & 0.10 & 0.25 & 0.36 & 0.01 & 0.18 \\
\hline & TH64 & 0.16 & 0.25 & 0.15 & 0.13 & 0.25 & 0.40 & 0.22 & 0.01 \\
\hline \multirow[t]{2}{*}{$\mathrm{RC} 23$} & PE10 & 0.18 & 0.24 & 0.10 & 0.16 & 0.15 & 0.21 & 0.49 & 0.03 \\
\hline & TH65 & 0.04 & - & 0.16 & 0.12 & 0.12 & 0.15 & 0.66 & 0.16 \\
\hline \multirow[t]{3}{*}{$\mathrm{RC} 24$} & PE14 & 0.03 & 0.05 & 0.03 & 0.33 & 0.19 & 0.28 & 0.19 & 0.36 \\
\hline & OG39 & 0.13 & 0.03 & 0.25 & 0.02 & 0.41 & 0.01 & 0.06 & 0.49 \\
\hline & OG59 & 0.17 & 0.01 & 0.11 & 0.08 & 0.08 & 0.19 & 0.14 & 0.66 \\
\hline
\end{tabular}




\begin{tabular}{|l|l|l|l|l|l|l|l|r|r|} 
& TH66 & 0.12 & 0.12 & 0.10 & 0.06 & 0.19 & 0.08 & 0.03 & 0.52 \\
\hline & TH80 & 0.08 & 0.16 & 0.26 & 0.05 & 0.24 & 0.06 & 0.06 & 0.54 \\
\hline
\end{tabular}

\subsection{ERP readiness assessment factors}

Based on the results of PCA data processing using R software, the authors identify a new name for the sub-variable of each RC can be seen in Table 5. Then the authors continue to analysis with the weighting of 61 indicators using TOPSIS method where the name of the grouping for 24 sub-variables is based on the highest score for the preference score. The results of the TOPSIS processing for 10 the readiness factors that affect the success of ERP implementation are as follows: cross functional support (9.87\%), project champion $(9.14 \%)$, communication $(7.82 \%)$, vision and mission (6.98\%), transfer knowledge $(6.97 \%)$, process improvement $(5.98 \%)$, project planning $(5.19 \%)$, vendor engagement $(5.13 \%)$, commited to change $(4.12 \%)$, and open minded for changes $(4.05 \%)$. The results of the weight of ERP readiness assessment can be seen in Table 5 .

Table 5: The weight of ERP readiness assessment

\begin{tabular}{|c|c|c|c|c|c|c|c|}
\hline $\mathrm{RC}$ & No & $\begin{array}{l}\text { Indica- } \\
\text { tors }\end{array}$ & Sub-variables & $\begin{array}{c}\text { Main } \\
\text { weights }\end{array}$ & $\begin{array}{c}\text { Final } \\
\text { weights }\end{array}$ & $\begin{array}{l}\text { Weights } \\
\text { factors }\end{array}$ & $\begin{array}{r}\text { Prefe } \\
\text { rences }\end{array}$ \\
\hline \multirow{7}{*}{ RC01 } & 1 & OG28 & \multirow{7}{*}{$\begin{array}{l}\text { Project } \\
\text { champion }\end{array}$} & \multirow{7}{*}{$9.14 \%$} & 15.75 & 1.44 & 0.77 \\
\hline & 2 & OG27 & & & 15.43 & 1.41 & 0.75 \\
\hline & 3 & PE22 & & & 14.11 & 1.29 & 0.68 \\
\hline & 4 & OG26 & & & 14,00 & 1.28 & 0.68 \\
\hline & 5 & OG43 & & & 13.79 & 1.26 & 0.67 \\
\hline & 6 & TH61 & & & 13.46 & 1.23 & 0.66 \\
\hline & 7 & OG38 & & & 13.46 & 1.23 & 0.65 \\
\hline \multirow{8}{*}{$\mathrm{RC} 02$} & 8 & OG30 & \multirow{8}{*}{$\begin{array}{l}\text { Cross } \\
\text { functional } \\
\text { support }\end{array}$} & \multirow{8}{*}{$9.87 \%$} & 13.98 & 1.38 & 0.73 \\
\hline & 9 & OG29 & & & 13.78 & 1.36 & 0.72 \\
\hline & 10 & OG36 & & & 13.48 & 1.33 & 0.71 \\
\hline & 11 & OG33 & & & 13.07 & 1.29 & 0.68 \\
\hline & 12 & OG31 & & & 12.56 & 1.24 & 0.66 \\
\hline & 13 & PR06 & & & 11.65 & 1.15 & 0.61 \\
\hline & 14 & OG32 & & & 11.04 & 1.09 & 0.58 \\
\hline & 15 & OG34 & & & 10.44 & 1.03 & 0.55 \\
\hline \multirow{2}{*}{$\mathrm{RC} 03$} & 16 & TH62 & \multirow{2}{*}{$\begin{array}{l}\text { Configuration } \\
\text { system }\end{array}$} & \multirow{2}{*}{$2.42 \%$} & 52.89 & 1.28 & 0.68 \\
\hline & 17 & TH63 & & & 47.11 & 1.14 & 0.60 \\
\hline \multirow{4}{*}{$\mathrm{RC} 04$} & 18 & TH79 & \multirow{4}{*}{$\begin{array}{l}\text { Vendor } \\
\text { engagement }\end{array}$} & \multirow{4}{*}{$5.13 \%$} & 28.07 & 1.44 & 0.77 \\
\hline & 19 & TH77 & & & 25.34 & 1.30 & 0.69 \\
\hline & 20 & TH78 & & & 25.15 & 1.29 & 0.69 \\
\hline & 21 & TH74 & & & 21.44 & 1.10 & 0.59 \\
\hline \multirow{3}{*}{$\mathrm{RC} 05$} & 22 & PR01 & \multirow{3}{*}{$\begin{array}{l}\text { Committed to } \\
\text { change }\end{array}$} & \multirow{3}{*}{$4.12 \%$} & 35.19 & 1.45 & 0.77 \\
\hline & 23 & PR04 & & & 33.98 & 1.40 & 0.74 \\
\hline & 24 & PR05 & & & 30.83 & 1.27 & 0.67 \\
\hline RC06 & 25 & OG58 & $\begin{array}{l}\begin{array}{l}\text { Project } \\
\text { planning } \\
\text { (budget) }\end{array} \\
\end{array}$ & $1.24 \%$ & 100,00 & 1.24 & 0.66 \\
\hline \multirow{2}{*}{ RC07 } & 26 & TH75 & \multirow{2}{*}{$\begin{array}{l}\text { Helpdesk } \\
\text { system }\end{array}$} & \multirow{2}{*}{$2.43 \%$} & 53.09 & 1.29 & 0.69 \\
\hline & 27 & TH76 & & & 46.91 & 1.14 & 0.61 \\
\hline \multirow{3}{*}{$\mathrm{RC} 08$} & 28 & OG48 & \multirow{3}{*}{$\begin{array}{l}\text { Data \& } \\
\text { information } \\
\text { standarization }\end{array}$} & \multirow{3}{*}{$3.59 \%$} & 35.1 & 1.26 & 0.67 \\
\hline & 29 & OG41 & & & 32.87 & 1.18 & 0.63 \\
\hline & 30 & OG42 & & & 32.03 & 1.15 & 0.61 \\
\hline \multirow{3}{*}{ RC09 } & 31 & PR07 & \multirow{3}{*}{$\begin{array}{l}\text { Open minded } \\
\text { for changes }\end{array}$} & \multirow{3}{*}{$4.05 \%$} & 35.31 & 1.43 & 0.76 \\
\hline & 32 & PE11 & & & 33.58 & 1.36 & 0.72 \\
\hline & 33 & PE12 & & & 31.11 & 1.26 & 0.67 \\
\hline \multirow{3}{*}{$\mathrm{RC} 10$} & 34 & PE25 & \multirow{3}{*}{$\begin{array}{l}\text { Employee } \\
\text { involvement }\end{array}$} & & 33.73 & 1.14 & 0.60 \\
\hline & 35 & PE20 & & $3.38 \%$ & 33.43 & 1.13 & 0.60 \\
\hline & 36 & PE21 & & & 32.84 & 1.11 & 0.59 \\
\hline $\mathrm{RC} 11$ & 37 & PE08 & $\begin{array}{l}\text { Management's } \\
\text { skill \& } \\
\text { competency }\end{array}$ & $1.27 \%$ & 100,00 & 1.27 & 0.68 \\
\hline
\end{tabular}

\begin{tabular}{|c|c|c|c|c|c|c|c|}
\hline $\mathrm{RC}$ & No & $\begin{array}{l}\text { Indica- } \\
\text { tors }\end{array}$ & Sub-variables & $\begin{array}{c}\text { Main } \\
\text { weights }\end{array}$ & $\begin{array}{c}\text { Final } \\
\text { weights }\end{array}$ & $\begin{array}{l}\text { Weights } \\
\text { factors }\end{array}$ & $\begin{array}{l}\text { Prefe } \\
\text { rences }\end{array}$ \\
\hline \multirow[b]{2}{*}{$\mathrm{RC} 12$} & 38 & PR02 & \multirow{2}{*}{$\begin{array}{c}\text { Business } \\
\text { processes } \\
\text { change }\end{array}$} & \multirow[b]{2}{*}{$2.7 \%$} & 50.37 & 1.36 & 0.72 \\
\hline & 39 & PR03 & & & 49.63 & 1.34 & 0.71 \\
\hline $\mathrm{RC} 13$ & 40 & OG49 & & $7.82 \%$ & 19.05 & 1.49 & 0.79 \\
\hline
\end{tabular}

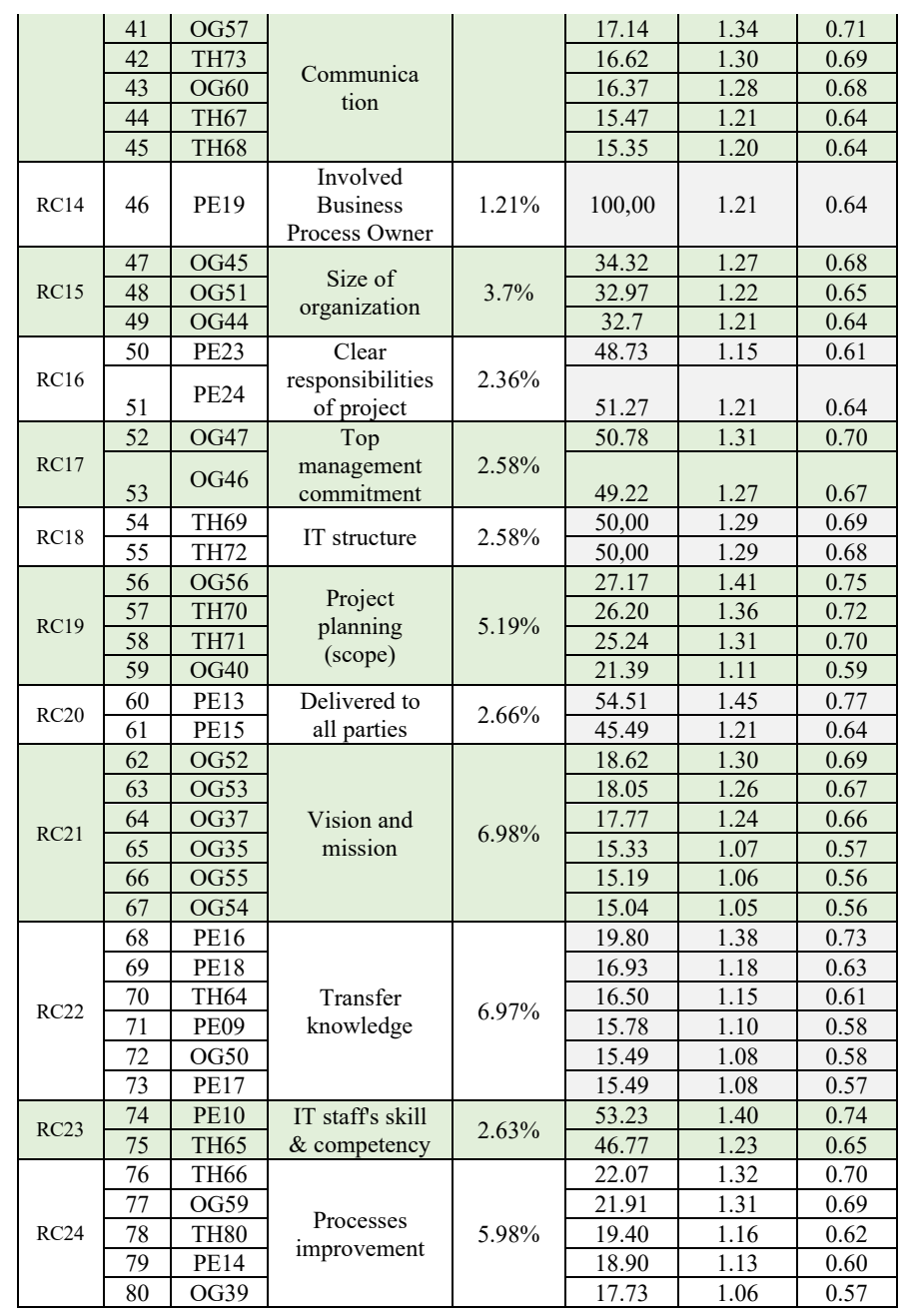

The results of data processing using TOPSIS, found that organizational variables have the main weight of $43.51 \%$, variable technology has the main weight of $25.03 \%$, variable people have the main weight of $22.06 \%$, and variable processes have the main weight of $9.40 \%$. Thus, the organizational variable is a very dominant variable that determines the level of readiness in implementing ERP for the textile industry in Indonesia. The main weight of variables can be seen in the Table 6 .

Table 6: Main weight of variables

\begin{tabular}{|c|l|r|}
\hline No & Variable & Main Weight \\
\hline 1 & Organizational & 43.51 \\
\hline 2 & Technology & 25.03 \\
\hline 3 & People & 22.06 \\
\hline 4 & Processes & 9.40 \\
\hline \multicolumn{2}{|l|}{} & 100.00 \\
\hline
\end{tabular}

Meanwhile, the teen sub-variables that have a significant main weight can be seen in the Table 7 .

Table 7: Weight of sub-variables

\begin{tabular}{|c|l|c|}
\hline No & \multicolumn{1}{|c|}{ Sub-variables } & $\begin{array}{c}\text { Main } \\
\text { weight }\end{array}$ \\
\hline 1 & Cross functional support & 9.87 \\
\hline 2 & Project champion & 9.14 \\
\hline 3 & Communication & 7.82 \\
\hline
\end{tabular}




\begin{tabular}{|c|l|c|}
\hline 4 & Vision and mission & 6.98 \\
\hline 5 & Transfer knowledge & 6.97 \\
\hline 6 & Processes improvement & 5.98 \\
\hline 7 & Project planning (scope) & 5.19 \\
\hline 8 & Vendor engagement & 5.13 \\
\hline 9 & Committed to change & 4.12 \\
\hline 10 & Open minded for changes & 4.05 \\
\hline
\end{tabular}

\subsection{Measuring the level of organizational maturity}

Based on the weighting of 24 indicators which are the results of data processing using TOPSIS, the authors make a list of questions as a basis for designing an ERP readiness assessment module. The list of assessment questions is in the form of a rubric assessment with the maturity level of the Capability Maturity Model Integration (CMMI) model with being considered the characteristic of initial, defined, managed, measured, and optimized with the readiness of process, people, organizational and technology. The list of Rubric Maturity Assessments can be seen in Table 8.

This rubric assessment will be a reference for the top management or the consultant to test each department involved to get good feedback before implementing ERP for the industry.

Table 8: Rubric Maturity Assessment

\begin{tabular}{|c|c|c|c|c|c|c|}
\hline \multirow{2}{*}{ No } & \multirow{2}{*}{ Sub-variables } & \multicolumn{5}{|c|}{ MATURITY LEVEL } \\
\hline & & INITIAL & DEFINED & MANAGED & MEASURED & OPTIMIZED \\
\hline 1 & $\begin{array}{l}\text { Project } \\
\text { champion }\end{array}$ & $\begin{array}{l}\text { The function of a } \\
\text { Project Champion in } \\
\text { project ERP has not } \\
\text { been defined }\end{array}$ & $\begin{array}{l}\text { The function of a Project } \\
\text { Champion in project } \\
\text { ERP has been defined }\end{array}$ & $\begin{array}{l}\text { The function of a Project } \\
\text { Champion in project ERP } \\
\text { have been standardized in } \\
\text { SOP }\end{array}$ & $\begin{array}{c}\text { The function of a Project } \\
\text { Champion in project ERP has } \\
\text { been socialized }\end{array}$ & $\begin{array}{l}\text { The function of a Project } \\
\text { Champion in project ERP has been } \\
\text { evaluated for improvement }\end{array}$ \\
\hline 2 & $\begin{array}{l}\text { Cross } \\
\text { functional } \\
\text { support }\end{array}$ & $\begin{array}{l}\text { Support from } \\
\text { organizational functions } \\
\text { in ERP implementation } \\
\text { is still informal }\end{array}$ & $\begin{array}{c}\text { Support from } \\
\text { organizational functions } \\
\text { in implementing ERP } \\
\text { has been standardized in } \\
\text { SOPs } \\
\end{array}$ & $\begin{array}{l}\text { Support from organizational } \\
\text { functions in implementing } \\
\text { ERP has been disseminated }\end{array}$ & $\begin{array}{l}\text { Support from organizational } \\
\text { functions in implementing ERP } \\
\text { has been integrated across } \\
\text { departments }\end{array}$ & $\begin{array}{l}\text { Support from organizational } \\
\text { functions in implementing ERP } \\
\text { has been evaluated for } \\
\text { improvement }\end{array}$ \\
\hline 3 & $\begin{array}{l}\text { Configuration } \\
\text { system }\end{array}$ & $\begin{array}{l}\text { The system hardware } \\
\text { and software } \\
\text { configurations affecting } \\
\text { the success of ERP } \\
\text { implementation have } \\
\text { not been identified }\end{array}$ & $\begin{array}{l}\text { The system hardware } \\
\text { and software } \\
\text { configurations that affect } \\
\text { the successful } \\
\text { implementation of ERP } \\
\text { have been identified } \\
\end{array}$ & $\begin{array}{l}\text { The configuration of the } \\
\text { hardware and software } \\
\text { systems that affect the } \\
\text { success of ERP } \\
\text { implementation has been } \\
\text { standardized in the SOP }\end{array}$ & $\begin{array}{l}\text { The configuration of hardware } \\
\text { and software systems that affect } \\
\text { the success of ERP } \\
\text { implementation has been } \\
\text { socialized }\end{array}$ & $\begin{array}{l}\text { The hardware and software system } \\
\text { configurations that affect the } \\
\text { success of ERP implementation } \\
\text { have been evaluated for } \\
\text { improvement }\end{array}$ \\
\hline 4 & $\begin{array}{l}\text { Vendor } \\
\text { engagement }\end{array}$ & $\begin{array}{l}\text { Relationships and } \\
\text { agreements with } \\
\text { vendors that can speed } \\
\text { up problem solving } \\
\text { related to the ERP } \\
\text { implementation process } \\
\text { have not yet been } \\
\text { identified } \\
\end{array}$ & $\begin{array}{l}\text { Relationships and } \\
\text { agreements with vendors } \\
\text { that can speed up } \\
\text { problem solving related } \\
\text { to the ERP } \\
\text { implementation process } \\
\text { have been identified }\end{array}$ & $\begin{array}{l}\text { Relationships and } \\
\text { agreements with vendors } \\
\text { that can speed up problem } \\
\text { solving related to the ERP } \\
\text { implementation process } \\
\text { have been standardized in } \\
\text { the SOP }\end{array}$ & $\begin{array}{l}\text { Relationships and agreements } \\
\text { with vendors that can speed up } \\
\text { problem solving related to the } \\
\text { ERP implementation process } \\
\text { have been integrated with the } \\
\text { customer }\end{array}$ & $\begin{array}{l}\text { Relationships and agreements with } \\
\text { vendors that can speed up problem } \\
\text { solving related to the ERP } \\
\text { implementation process have been } \\
\text { evaluated for improvement }\end{array}$ \\
\hline 5 & $\begin{array}{l}\text { Committed to } \\
\text { change }\end{array}$ & $\begin{array}{l}\text { Management's } \\
\text { commitment to change } \\
\text { business processes is } \\
\text { still informal. }\end{array}$ & $\begin{array}{l}\text { Management's } \\
\text { commitment to changing } \\
\text { business processes has } \\
\text { been standardized in the } \\
\text { SOP. }\end{array}$ & $\begin{array}{l}\text { Management's commitment } \\
\text { to changing business } \\
\text { processes has been } \\
\text { socialized }\end{array}$ & $\begin{array}{l}\text { Management's commitment to } \\
\text { change business processes has } \\
\text { been synchronized with } \\
\text { business strategy }\end{array}$ & $\begin{array}{l}\text { Management's commitment to } \\
\text { changing business processes has } \\
\text { been evaluated for improvement }\end{array}$ \\
\hline 6 & $\begin{array}{l}\text { Project } \\
\text { planning } \\
\text { (budget) }\end{array}$ & $\begin{array}{l}\text { The budget usage that } \\
\text { must be strictly } \\
\text { controlled during ERP } \\
\text { implementation has not } \\
\text { been defined }\end{array}$ & $\begin{array}{l}\text { The use of budgets that } \\
\text { must be strictly } \\
\text { controlled during ERP } \\
\text { implementation has been } \\
\text { determined } \\
\end{array}$ & $\begin{array}{c}\text { The use of budgets that } \\
\text { must be strictly controlled } \\
\text { during ERP implementation } \\
\text { has been standardized in the } \\
\text { SOP }\end{array}$ & $\begin{array}{l}\text { The use of budgets that must be } \\
\text { strictly controlled during ERP } \\
\text { implementation has been } \\
\text { socialized }\end{array}$ & $\begin{array}{l}\text { The use of budgets that must be } \\
\text { strictly controlled during ERP } \\
\text { implementation has been evaluated } \\
\text { for improvement }\end{array}$ \\
\hline 7 & $\begin{array}{l}\text { Helpdesk } \\
\text { system }\end{array}$ & $\begin{array}{l}\text { The availability of a } \\
\text { helpdesk system can } \\
\text { help users quickly solve } \\
\text { problems related to the } \\
\text { use of ERP that have } \\
\text { not been identified }\end{array}$ & $\begin{array}{l}\text { The availability of a } \\
\text { helpdesk system can } \\
\text { help users quickly solve } \\
\text { problems related to the } \\
\text { use of ERP that have } \\
\text { been identified }\end{array}$ & $\begin{array}{l}\text { The availability of a } \\
\text { helpdesk system can help } \\
\text { users quickly solve } \\
\text { problems related to the use } \\
\text { of ERP that have } \\
\text { standardized in the SOP }\end{array}$ & $\begin{array}{l}\text { The availability of a helpdesk } \\
\text { system can help users quickly } \\
\text { solve problems related to the } \\
\text { use of ERP that have been } \\
\text { socialized }\end{array}$ & $\begin{array}{c}\text { The availability of a helpdesk } \\
\text { system can help users quickly } \\
\text { solve problems related to the use } \\
\text { of ERP that have evaluated for } \\
\text { improvement }\end{array}$ \\
\hline 8 & $\begin{array}{l}\text { Data \& } \\
\text { information } \\
\text { standarization }\end{array}$ & $\begin{array}{l}\text { Standardization of data } \\
\text { and information on all } \\
\text { business operations has } \\
\text { not been identified }\end{array}$ & $\begin{array}{l}\text { Standardization of data } \\
\text { and information on all } \\
\text { business operations has } \\
\text { been identified }\end{array}$ & $\begin{array}{l}\text { Standardization of data and } \\
\text { information on all business } \\
\text { operations has standardized } \\
\text { in the SOP }\end{array}$ & $\begin{array}{l}\text { Standardization of data and } \\
\text { information on all business } \\
\text { operations has been socialized }\end{array}$ & $\begin{array}{l}\text { Standardization of data and } \\
\text { information on all business } \\
\text { operations has evaluated for } \\
\text { improvement }\end{array}$ \\
\hline 9 & $\begin{array}{l}\text { Open minded } \\
\text { for changes }\end{array}$ & $\begin{array}{l}\text { Not all parties involved } \\
\text { have an open mind in } \\
\text { accepting the change } \\
\text { process }\end{array}$ & $\begin{array}{l}\text { All parties involved have } \\
\text { an open mind in } \\
\text { accepting the change } \\
\text { process has been } \\
\text { identified }\end{array}$ & $\begin{array}{l}\text { All parties involved have an } \\
\text { open mind in accepting the } \\
\text { change process has been } \\
\text { standardized in the SOP }\end{array}$ & $\begin{array}{l}\text { All parties involved have an } \\
\text { open mind in accepting the } \\
\text { change process has been } \\
\text { socialized }\end{array}$ & $\begin{array}{l}\text { All parties involved have an open } \\
\text { mind in accepting the change } \\
\text { process has evaluated for } \\
\text { improvement }\end{array}$ \\
\hline 10 & $\begin{array}{l}\text { Employee } \\
\text { involvement }\end{array}$ & $\begin{array}{l}\text { Being actively involved } \\
\text { in ERP implementation } \\
\text { has not been identified }\end{array}$ & $\begin{array}{l}\text { Being actively involved } \\
\text { in ERP implementation } \\
\text { has been identified }\end{array}$ & $\begin{array}{l}\text { Being actively involved in } \\
\text { ERP implementation has } \\
\text { been standardized in the } \\
\text { SOP }\end{array}$ & $\begin{array}{l}\text { Being actively involved in ERP } \\
\text { implementation has been } \\
\text { socialized }\end{array}$ & $\begin{array}{l}\text { Being actively involved in ERP } \\
\text { implementation has evaluated for } \\
\text { improvement }\end{array}$ \\
\hline
\end{tabular}




\begin{tabular}{|c|c|c|c|c|c|c|}
\hline \multirow[t]{2}{*}{ No } & \multirow{2}{*}{ Sub-variables } & \multicolumn{5}{|c|}{ MATURITY LEVEL } \\
\hline & & INITIAL & DEFINED & MANAGED & MEASURED & OPTIMIZED \\
\hline 11 & $\begin{array}{l}\text { Management's } \\
\text { skill \& } \\
\text { competency }\end{array}$ & $\begin{array}{l}\text { Management does not } \\
\text { yet have expertise in } \\
\text { determining strategies } \\
\text { for utilizing ERP for } \\
\text { business development }\end{array}$ & $\begin{array}{c}\text { Management already has } \\
\text { expertise in determining } \\
\text { ERP utilization strategies } \\
\text { for business } \\
\text { development }\end{array}$ & $\begin{array}{l}\text { Management already has } \\
\text { expertise in determining } \\
\text { ERP utilization strategies } \\
\text { for business development } \\
\text { and has been standardized } \\
\text { in SOPs } \\
\end{array}$ & $\begin{array}{l}\text { Management already has } \\
\text { expertise in determining ERP } \\
\text { utilization strategies for } \\
\text { business development and has } \\
\text { been socialized }\end{array}$ & $\begin{array}{l}\text { Management already has expertise } \\
\text { in determining ERP utilization } \\
\text { strategies for business } \\
\text { development and has evaluated for } \\
\text { improvement }\end{array}$ \\
\hline 12 & $\begin{array}{l}\text { Business } \\
\text { processes } \\
\text { change }\end{array}$ & $\begin{array}{l}\text { Changes in business } \\
\text { processes are still } \\
\text { informal. }\end{array}$ & $\begin{array}{l}\text { Changes in business } \\
\text { processes has been } \\
\text { standardized in SOPs }\end{array}$ & $\begin{array}{l}\text { Changes in business } \\
\text { processes has been } \\
\text { socialized }\end{array}$ & $\begin{array}{l}\text { Changes in business processes } \\
\text { has been integrated }\end{array}$ & $\begin{array}{l}\text { Changes in business processes has } \\
\text { evaluated for improvement }\end{array}$ \\
\hline 13 & $\begin{array}{l}\text { Communica } \\
\text { tion }\end{array}$ & $\begin{array}{l}\text { The objectives and } \\
\text { objectivity of the } \\
\text { project are } \\
\text { communicated } \\
\text { effectively to the } \\
\text { stakeholders involved } \\
\text { but have not been } \\
\text { identified }\end{array}$ & $\begin{array}{l}\text { The objectives and } \\
\text { objectivity of the project } \\
\text { are communicated } \\
\text { effectively to the } \\
\text { stakeholders involved, \& } \\
\text { have been identified }\end{array}$ & $\begin{array}{l}\text { The objectives and } \\
\text { objectivity of the project are } \\
\text { communicated effectively to } \\
\text { the stakeholders involved, } \\
\& \text { have been standardized in } \\
\text { SOPs }\end{array}$ & $\begin{array}{l}\text { The objectives and objectivity } \\
\text { of the project are } \\
\text { communicated effectively to } \\
\text { the stakeholders involved, \& } \\
\text { have been socialized }\end{array}$ & $\begin{array}{l}\text { The objectives and objectivity of } \\
\text { the project are communicated } \\
\text { effectively to the stakeholders } \\
\text { involved, \& have been evaluated } \\
\text { for improvement }\end{array}$ \\
\hline 14 & $\begin{array}{l}\text { Involved } \\
\text { Business } \\
\text { Process Owner }\end{array}$ & $\begin{array}{l}\text { ERP business process } \\
\text { mapping has not been } \\
\text { defined. }\end{array}$ & $\begin{array}{l}\text { ERP business process } \\
\text { mapping has been } \\
\text { defined. }\end{array}$ & $\begin{array}{l}\text { ERP business process } \\
\text { mapping have been } \\
\text { standardized in SOPs }\end{array}$ & $\begin{array}{l}\text { ERP business process mapping } \\
\text { have been socialized }\end{array}$ & $\begin{array}{l}\text { ERP business process mapping } \\
\text { have been evaluated for } \\
\text { improvement }\end{array}$ \\
\hline 15 & $\begin{array}{l}\text { Size of } \\
\text { organization }\end{array}$ & $\begin{array}{l}\text { The organizational size } \\
\text { that affects the success } \\
\text { of an ERP project has } \\
\text { not been defined }\end{array}$ & $\begin{array}{l}\text { The organizational size } \\
\text { that affects the success } \\
\text { of an ERP project has } \\
\text { been defined }\end{array}$ & $\begin{array}{l}\text { The organizational size that } \\
\text { affects the success of an } \\
\text { ERP project has been } \\
\text { standardized in SOPs }\end{array}$ & $\begin{array}{l}\text { The organizational size that } \\
\text { affects the success of an ERP } \\
\text { project has been socialized }\end{array}$ & $\begin{array}{l}\text { The organizational size that affects } \\
\text { the success of an ERP project has } \\
\text { been evaluated for improvement }\end{array}$ \\
\hline 16 & $\begin{array}{l}\text { Clear } \\
\text { responsibilities } \\
\text { of project }\end{array}$ & $\begin{array}{l}\text { The roles of project } \\
\text { stakeholders have not } \\
\text { been defined }\end{array}$ & $\begin{array}{l}\text { The roles of project } \\
\text { stakeholders have been } \\
\text { defined }\end{array}$ & $\begin{array}{c}\text { The roles of project } \\
\text { stakeholders have been } \\
\text { standardized in SOPs }\end{array}$ & $\begin{array}{l}\text { The roles of project } \\
\text { stakeholders have been } \\
\text { socialized }\end{array}$ & $\begin{array}{l}\text { The roles of project stakeholders } \\
\text { have been evaluated for } \\
\text { improvement }\end{array}$ \\
\hline 17 & $\begin{array}{l}\text { Top } \\
\text { management } \\
\text { commitment }\end{array}$ & $\begin{array}{l}\text { Top management has } \\
\text { not been actively } \\
\text { involved in every } \\
\text { process and monitors } \\
\text { the progress of the ERP } \\
\text { project } \\
\end{array}$ & $\begin{array}{l}\text { Top management has } \\
\text { been actively involved in } \\
\text { every process and } \\
\text { monitors the progress of } \\
\text { the ERP project }\end{array}$ & $\begin{array}{l}\text { Top management has been } \\
\text { actively involved in every } \\
\text { process and monitors the } \\
\text { progress of the ERP project, } \\
\& \text { have been standardized in } \\
\text { SOPs } \\
\end{array}$ & $\begin{array}{l}\text { Top management has been } \\
\text { actively involved in every } \\
\text { process and monitors the } \\
\text { progress of the ERP project, \& } \\
\text { have been socialized }\end{array}$ & $\begin{array}{l}\text { Top management has been actively } \\
\text { involved in every process and } \\
\text { monitors the progress of the ERP } \\
\text { project, \& have been evaluated for } \\
\text { improvement }\end{array}$ \\
\hline 18 & IT structure & $\begin{array}{l}\text { The IT team structure to } \\
\text { coordinate ERP project } \\
\text { activities from planning } \\
\text { to post-go live has not } \\
\text { been identified }\end{array}$ & $\begin{array}{l}\text { The IT team structure to } \\
\text { coordinate ERP project } \\
\text { activities from planning } \\
\text { to post-go live has been } \\
\text { identified }\end{array}$ & $\begin{array}{l}\text { The IT team structure to } \\
\text { coordinate ERP project } \\
\text { activities from planning to } \\
\text { post-go live has been } \\
\text { identified, \& have been } \\
\text { standardized in SOPs } \\
\end{array}$ & $\begin{array}{l}\text { The IT team structure to } \\
\text { coordinate ERP project } \\
\text { activities from planning to post- } \\
\text { go live has been identified, \& } \\
\text { have been socialized }\end{array}$ & $\begin{array}{l}\text { The IT team structure to } \\
\text { coordinate ERP project activities } \\
\text { from planning to post-go live has } \\
\text { been identified, \& have been } \\
\text { evaluated for improvement }\end{array}$ \\
\hline 19 & $\begin{array}{l}\text { Project } \\
\text { planning } \\
\text { (scope) }\end{array}$ & $\begin{array}{l}\text { The scope of the ERP } \\
\text { project in determining } \\
\text { the success of ERP } \\
\text { implementation has not } \\
\text { been defined }\end{array}$ & $\begin{array}{l}\text { The scope of the ERP } \\
\text { project in determining } \\
\text { the success of ERP } \\
\text { implementation has been } \\
\text { defined } \\
\end{array}$ & $\begin{array}{l}\text { The scope of the ERP } \\
\text { project in determining the } \\
\text { success of ERP } \\
\text { implementation have been } \\
\text { standardized in SOPs }\end{array}$ & $\begin{array}{l}\text { The scope of the ERP project in } \\
\text { determining the success of ERP } \\
\text { implementation have been } \\
\text { socialized }\end{array}$ & $\begin{array}{l}\text { The scope of the ERP project in } \\
\text { determining the success of ERP } \\
\text { implementation have been } \\
\text { evaluated for improvement }\end{array}$ \\
\hline 20 & $\begin{array}{l}\text { Delivered to } \\
\text { all parties }\end{array}$ & $\begin{array}{l}\text { Training activities have } \\
\text { not been delivered to all } \\
\text { parties involved. }\end{array}$ & $\begin{array}{l}\text { Training activities have } \\
\text { been delivered to all } \\
\text { parties involved. }\end{array}$ & $\begin{array}{l}\text { Training activities have } \\
\text { been delivered to all parties } \\
\text { involved, \& have been } \\
\text { standardized in SOPs }\end{array}$ & $\begin{array}{l}\text { Training activities have been } \\
\text { delivered to all parties } \\
\text { involved, \& have been } \\
\text { socialized }\end{array}$ & $\begin{array}{c}\text { Training activities have been } \\
\text { delivered to all parties involved, \& } \\
\text { have been evaluated for } \\
\text { improvement }\end{array}$ \\
\hline 21 & $\begin{array}{l}\text { Vision and } \\
\text { mission }\end{array}$ & $\begin{array}{l}\text { The vision and mission } \\
\text { of the organization that } \\
\text { was revealed and } \\
\text { communicated to all } \\
\text { parties involved to } \\
\text { support the } \\
\text { implementation of the } \\
\text { ERP project has not } \\
\text { been defined }\end{array}$ & $\begin{array}{l}\text { The vision and mission } \\
\text { of the organization that } \\
\text { was revealed and } \\
\text { communicated to all } \\
\text { parties involved to } \\
\text { support the } \\
\text { implementation of the } \\
\text { ERP project has been } \\
\text { defined }\end{array}$ & $\begin{array}{l}\text { The vision and mission of } \\
\text { the organization that was } \\
\text { revealed and communicated } \\
\text { to all parties involved to } \\
\text { support the implementation } \\
\text { of the ERP project has been } \\
\text { defined, \& have been } \\
\text { standardized in SOPs }\end{array}$ & $\begin{array}{l}\text { The vision and mission of the } \\
\text { organization that was revealed } \\
\text { and communicated to all parties } \\
\text { involved to support the } \\
\text { implementation of the ERP } \\
\text { project has been defined, \& } \\
\text { have been socialized }\end{array}$ & $\begin{array}{l}\text { The vision and mission of the } \\
\text { organization that was revealed and } \\
\text { communicated to all parties } \\
\text { involved to support the } \\
\text { implementation of the ERP project } \\
\text { has been defined, \& have been } \\
\text { evaluated for improvement }\end{array}$ \\
\hline 22 & $\begin{array}{l}\text { Transfer } \\
\text { knowledge }\end{array}$ & $\begin{array}{l}\text { There is no awareness } \\
\text { from users and the } \\
\text { benefits of knowledge } \\
\text { transfer to improve the } \\
\text { quality of users }\end{array}$ & $\begin{array}{l}\text { There is awareness from } \\
\text { users and the benefits of } \\
\text { knowledge transfer to } \\
\text { improve the quality of } \\
\text { users }\end{array}$ & $\begin{array}{l}\text { There is awareness from } \\
\text { users and the benefits of } \\
\text { knowledge transfer to } \\
\text { improve the quality of } \\
\text { users, \& have been } \\
\text { standardized in SOPs }\end{array}$ & $\begin{array}{l}\text { There is awareness from users } \\
\text { and the benefits of knowledge } \\
\text { transfer to improve the quality } \\
\text { of users, \& have been } \\
\text { socialized }\end{array}$ & $\begin{array}{c}\text { There is awareness from users and } \\
\text { the benefits of knowledge transfer } \\
\text { to improve the quality of users, \& } \\
\text { have been evaluated for } \\
\text { improvement }\end{array}$ \\
\hline 23 & $\begin{array}{l}\text { IT staff's skill } \\
\& \text { competency }\end{array}$ & $\begin{array}{l}\text { IT Staff does not have } \\
\text { the expertise \& } \\
\text { experience in } \\
\text { understanding the } \\
\text { business processes of } \\
\text { the system used. }\end{array}$ & $\begin{array}{l}\text { IT Staff have the } \\
\text { expertise \& experience } \\
\text { in understanding the } \\
\text { business processes of the } \\
\text { system used. }\end{array}$ & $\begin{array}{l}\text { IT Staff have the expertise } \\
\& \text { experience in } \\
\text { understanding the business } \\
\text { processes of the system } \\
\text { used, \& have been } \\
\text { standardized in SOPs }\end{array}$ & $\begin{array}{l}\text { IT Staff have the expertise \& } \\
\text { experience in understanding the } \\
\text { business processes of the } \\
\text { system used, \& have been } \\
\text { socialized }\end{array}$ & $\begin{array}{l}\text { IT Staff have the expertise \& } \\
\text { experience in understanding the } \\
\text { business processes of the system } \\
\text { used, \& have been evaluated for } \\
\text { improvement }\end{array}$ \\
\hline 24 & $\begin{array}{l}\text { Processes } \\
\text { improvement }\end{array}$ & $\begin{array}{l}\text { The identification of } \\
\text { process improvements } \\
\text { before ERP } \\
\text { implementation has not } \\
\text { been identified }\end{array}$ & $\begin{array}{l}\text { The identification of } \\
\text { process improvements } \\
\text { before ERP } \\
\text { implementation has been } \\
\text { identified } \\
\end{array}$ & $\begin{array}{l}\text { The identification of } \\
\text { process improvements } \\
\text { before ERP implementation } \\
\text { have been standardized in } \\
\text { SOPs }\end{array}$ & $\begin{array}{l}\text { The identification of process } \\
\text { improvements before ERP } \\
\text { implementation have been } \\
\text { socialized }\end{array}$ & $\begin{array}{l}\text { The identification of process } \\
\text { improvements before ERP } \\
\text { implementation have been } \\
\text { evaluated for improvement }\end{array}$ \\
\hline
\end{tabular}




\section{Conclusion}

The ERP implementation process for the industry has a high complexity, which will risk a high failure rate. However, the problem of the complexity of ERP implementation in the textile industry can be resolved by identifying readiness factors that focus on four main components such as processes, people, organizational, and technology before implementing ERP. Thus, the organizations can identify weaknesses and anticipate improvements, thereby increasing the success rate of ERP implementation. The research result shows that the score of organizational variable is $43.50 \%$ and the domain factors that influence ERP readiness assessment with significance factors are project champion $(9.14 \%)$, cross-functional support $(9.87 \%)$, project planning scope $(5.19 \%)$, vision and mission $(6.98 \%)$, and communication $(7.82 \%)$. For this reason, it is necessary to develop of ERP readiness assessment, so that the managerial level can easily analyze the maturity level of the organization that need to be improved. The author realizes that this research has limitations in conducting case studies in the textile industry. For this reason, this research can be continued with case studies in the wider industry, and this research can also be developed by developing an ERP readiness assessment module as an information system for the management level in deciding to continue implementing ERP.

\section{References}

[1] M. Kirmizi, B. Kocaoglu, "The key for success in enterprise information systems projects: development of a novel ERP readiness assessment method and a case study," Enterprise Information Systems, 14(1), 1-37, 2020, doi:10.1080/17517575.2019.1686656.

[2] J. Ram, D. Corkindale, M.L. Wu, "Examining the role of organizational readiness in ERP project delivery," Journal of Computer Information Systems, 55(2), 29-39, 2015, doi:10.1080/08874417.2015.11645754.

[3] P. Hanafizadeh, A.Z. Ravasan, "A McKinsey 7S model-based framework for ERP readiness assessment," International Journal of Enterprise Information Systems, 7(4), 23-63, 2011, doi:10.4018/jeis.2011100103.

[4] J. Razmi, M.S. Sangari, R. Ghodsi, "Developing a practical framework for ERP readiness assessment using fuzzy analytic network process," Advances in Engineering Software, 40(11), 1168-1178, 2009, doi:10.1016/j.advengsoft.2009.05.002.

[5] S. De Soysa, J. Nanayakkara, "Readiness for ERP implementation in an organization: Development of an assessment model," 2nd International Conference on Information and Automation, ICIA 2006, 00, 27-32, 2006, doi:10.1109/ICINFA.2006.374147.

[6] M. El Mariouli, J. Laassiri, "Information Systems and Technologies to Support Learning," 111, 471-481, 2019, doi:10.1007/978-3-030-03577-8.

[7] J.R. Lavoie, T.U. Daim, "Technology readiness levels enhancing R\&D management and technology transfer capabilities: insights from a public utility in Northwest USA," International Journal of Transitions and Innovation Systems, 6(1), 48, 2018, doi:10.1504/ijtis.2018.10011690.

[8] S. Ahmadi, E. Papageorgiou, C.H. Yeh, R. Martin, "Managing readinessrelevant activities for the organizational dimension of ERP implementation," Computers in Industry, 68, 89-104, 2015, doi:10.1016/j.compind.2014.12.009.

[9] K.P. Subramaniya, C. Ajay Guru Dev, V.S. Senthilkumar, "Critical Success Factors: A TOPSIS approach to increase Agility Level in a Textile Industry," Materials Today: Proceedings, 4(2), 1510-1517, 2017, doi:10.1016/j.matpr.2017.01.173.

[10] S. Shiri, A. Anvari, H. Soltani, "Identifying and prioritizing of readiness factors for implementing ERP based on agility (extension of McKinsey 7S model)," European Online Journal of Natural and Social Sciences, 4(1), 5674, 2015.

[11] Harold J. Leavitt, "Applied Organizational Change in Industry, Structural, Technological Humanistic Approaches," Handbook of organizations, 1965.

[12] D. Sundiman, C.H. Wu, A. Mursidi, S.B.P. Johan, A. Indahingwati, "Knowledge management key factors: An empirical research on small and medium-sized enterprises in Indonesia," 13(2), 139-161, 2019 , doi:10.1504/IJBSR.2019.098650.

[13] C.L. Hwang, K. Yoon, "Methods for Multiple Attribute Decision Making," 58-191, 1981, doi:10.1007/978-3-642-48318-9_3.

[14] A.N. Hidayanto, M.A. Hasibuan, P.W. Handayani, Y.G. Sucahyo, "Framework for measuring ERP implementation readiness in small and medium enterprise (SME): A case study in software developer company," Journal of Computers (Finland), 8(7), 1777-1782, 2013, doi:10.4304/jcp.8.7.1777-1782.

[15] Meyliana, A.N. Hidayanto, E.K. Budiardjo, "The critical success factors for customer relationship management implementation: A systematic literature review," International Journal of Business Information Systems, 23(2), 131174, 2016, doi:10.1504/IJBIS.2016.078904.

[16] H. Sun, W. Ni, R. Lam, "A step-by-step performance assessment and improvement method for ERP implementation: Action case studies in Chinese companies," Computers in Industry, 68, 40-52, 2015, doi:10.1016/j.compind.2014.12.005.

[17] W.H. Tsai, Y.W. Chou, J. Der Leu, D.C. Chen, T.S. Tsaur, "Investigation of the mediating effects of IT governance-value delivery on service quality and ERP performance," Enterprise Information Systems, 9(2), 139-160, 2015, doi:10.1080/17517575.2013.804952.

[18] P.B. Tarigan, "Agile Enterprise Resource Planning Implementation: Improving ERP Implementation Success Rates," Journal of Chemical Information and Modeling, 53(9), 1689-1699, 2013, doi:10.1017/CBO9781107415324.004.

[19] S. Abdelkebir, Y. Maleh, M. Belaissaoui, "An Agile Framework for ITS Management In Organizations," In Proceedings of the 2nd International Conference on Computing and Wireless Communication Systems, 1-8, 2017, doi: $10.1145 / 3167486.3167556$. 